\title{
Seismic performance of RC frame buildings accounting for the out-of-plane behavior of masonry infills
}

\author{
G. Gesualdi ${ }^{1}$ - L. R. S. Viggiani ${ }^{1} \cdot$ D. Cardone ${ }^{1}$ (D)
}

Received: 21 December 2019 / Accepted: 6 July 2020 / Published online: 21 July 2020

(c) The Author(s) 2020

\begin{abstract}
Past earthquakes have repeatedly shown that damage to masonry infills can produce large economic losses and even jeopardize human lives. Nevertheless, in current design practice masonry infills are ignored, while available macro-models for nonlinear analysis focus the attention on the In-Plane (IP) behavior of masonry infills only, while neglecting the OutOf-Plane (OOP) collapse mechanism. The main objective of this study is to investigate the seismic performance of RC frame buildings accounting for the interaction between IP and OOP behavior of masonry infills. To this end, a suitable nonlinear model, able to capture the IP stiffness and strength reduction due to the OOP displacement demand (and vice versa) is implemented. The selected model incorporates a routine that removes infills from the structural model when either IP or OOP collapse occurs. Different building models, representative of typical residential buildings, realized in Italy (and other European countries) from 50's to 90's, are examined through nonlinear response-time history analysis at different earthquake intensity levels, with return period ranging from 30 to 5000 years. Two alternative infill configurations (single layer and double layer with inner cavity) are considered, in accordance with the construction practice of the time. The comparison between the models with and without IP/OOP interaction points out the relevance of the OOP behavior towards an accurate evaluation of the seismic performance of RC frame buildings. A set of fragility curves is tentatively proposed, for different building performance levels, ranging from immediate occupancy to life safety.
\end{abstract}

Keywords Seismic performance assessment $\cdot$ RC frame buildings $\cdot$ Masonry infill walls · In-plane/out-of-plane interaction $\cdot$ Nonlinear response time-history analyses

\section{Introduction}

UnReinforced Masonry (URM) infills are widely used in Reinforced Concrete (RC) frame buildings as internal partitions and exterior enclosure walls, because of their reliability against fire and moisture, good thermal and acoustic insulation, and low construction costs.

D. Cardone

donatello.cardone@unibas.it

1 School of Engineering, University of Basilicata, 85100 Potenza, Italy 
Typical configurations of URM walls include single or double layers of hollow clay bricks inserted in, and rigidly connected to, the RC frame. URM infills are usually considered as non-structural elements and are then neglected in the seismic design of the building. However, the presence of URM infills can significantly modify the global seismic response of the building, inducing both positive and negative effects (Fardis and Panagiotakos 1997). In principle, a regular distribution of the URM infills can considerably increases the peak strength and initial lateral stiffness of the structure (Dolšek and Fajfar 2008). Masonry infills can also increase the energy dissipation capacity of RC buildings, thus reducing the displacement demand imposed by the earthquake (Ozkaynak et al. 2013). On the other hand, infill walls can strongly interact with the surrounding RC frame, triggering the brittle shear failure of RC columns, thus strongly affecting the overall performance of the RC building (Furtado et al. 2015a).

Generally speaking, masonry infills feature two different brittle failure mechanisms, in the following referred to as In-Plane (IP) and Out-Of-Plane (OOP) collapse mechanism, both characterized by degradation of strength, stiffness and low energy dissipation (ElDakhakhni et al. 2003). In recent years, several strong earthquakes have repeatedly pointed out the high vulnerability of URM infills (Braga et al. 2011; Vicente et al. 2012; Varum et al. 2018), especially of those realized between 50's and 70's, featuring two thin layers (high height/thickness ratio) of hollow clay bricks with an inner cavity.

The damage scenario typically observed for masonry infills after strong earthquakes includes extensive diagonal cracking, corner crushing (De Luca et al. 2014), and sometimes the overturning of entire infill walls, usually located at the lower-to-mid storeys of the building (Ricci et al. 2011; Masi et al. 2019). As argued by Morandi et al. (2013), the OOP collapse of the infill walls located at the lower-to-mid storeys of the building indicates that they underwent a significant reduction of out-of-plane resistance (compared to the infill walls of the upper storeys) due to the larger interstory drift demand previously sustained.

Extensive damage to masonry infills can jeopardize the usability of a building after an earthquake with obvious important socio-economic consequences (Braga et al. 2011; Taghavi and Miranda 2002), including large economic losses for building repairing (Cardone and Perrone 2017). Moreover, the OOP collapse of URM walls might seriously threaten human life either inside or outside the building.

In current practice, the safety verification of OOP collapse mechanisms of infill walls is carried out following force-based pseudostatic approaches. A number of recommendations and semi-empirical relationships are proposed in modern seismic codes (FEMA306 1998; CEN 2005; NZSEE 2006) for the estimation of the OOP acceleration demand imposed by the design earthquake and the OOP strength of the infills, which in some cases also take into account the OOP strength reduction due to previous IP damage.

For all the above reasons, in these last decades, efforts have been made to develop analytical tools and computational models able to describe the seismic behavior of masonry infills and their interaction with RC frames. Micro-models and macro-models are the two alternative modeling strategies investigated by various authors (see Asteris et al. 2013 for a comprehensive state-of-the-art on this subject). Despite their accuracy, the use of micromodels is very complex, requiring large modelling efforts and long computational time, being based on non-linear finite elements modeling both $\mathrm{RC}$ frame, infill walls and the interface between RC frame and infill wall. Macro-models are much simpler than micromodels. Indeed, they are implemented through single- or multiple mono-dimensional elements described by a limited number of numerical parameters that can be calibrated from experimental results (Lam et al. 2003), in order to simulate the overall force-displacement behavior of the infill with low computational efforts. 
The development of macro-models for the description of the in-plane behavior of URM infills took place before and independently with respect to the development of analytical models for the out-of-plane behavior of infills.

Based on experimental tests carried out by Polyakov (1960), Holmes (1961) and Stafford-Smith (1962) first proposed a simple and low time-consuming macro-model, based on the assumption of an equivalent "strut", for the simulation of the IP behavior of masonry infills subjected to seismic loading. Mainstone (1971) derived a semiempirical equation for the calculation of the equivalent strut width. Subsequently, many authors proposed further improvements and developments to the equivalent strut model, in order to simulate the overall inelastic response under monotonic and cyclic loading (Mehrabi and Shing 1997; El-Dakhakhni et al. 2003; Panagiotakos and Fardis 1996), considering different IP failure mechanisms that may occur in masonry infills (Decanini et al. 2004; Sassun et al. 2016). Some of these specifications have been also included in international guidelines and standards for the seismic analysis and rehabilitation of buildings (FEMA 274 1997; CEN 2005). Finally, in the last years, a series of multistrut models, differing in the number and layout of diagonal struts, have been proposed (Crisafulli and Carr 2007; Smyrou et al. 2011) to capture the in-plane interaction between masonry infills and RC frame.

A number of analytical models for the estimation of the OOP strength of URM infills also exist. They have been derived from past experimental studies carried out by various researchers. McDowell et al. (1956), for instance, examined an analytical model to predict the maximum allowable uniformly distributed load pattern considering a one-way arch mechanism. Bashandy et al. (1995) and Dawe and Seah (1989) extended the approach proposed by McDowell et al. (1956) following the principle of virtual works, thus deriving semi-empirical relationships for one-way and two-ways arch mechanisms. Flanagan and Bennett (1999) simplified the formulation derived by Dawe and Seah (1989) based on experimental results. A detailed state-of-the-art on OOP strength models for URM infill walls can be found in Pasca and Liberatore (2015).

So far, only a few experimental studies have been performed to investigate the interaction between IP and OOP behavior of masonry infills.

Based on experimental tests on full-scale infilled steel frames, Henderson et al. (2006) showed that OOP damage reduces the IP initial stiffness, with a limited effect on the initial IP strength of the wall. Similar results were obtained by Angel et al. (1994), Calvi and Bolognini (2001) and Furtado et al. (2015b), based on tests on full- and reduced-scale infilled RC frames. In all these experimental tests, clay brick URM infills with slenderness ratio (height/thickness) ranging from 15.3 to 33.9 were tested considering either concentrated or uniformly distributed load patterns. Such studies showed that preliminary IP damage can yield a significant reduction of the OOP strength (even higher than 50\%), especially for infill walls with high slenderness ratio. Furtado et al. (2015b) proved that OOP infill strength is not significantly influenced by the axial load on columns and/or type of loading path (monotonic or cyclic). Extensive experimental tests, on full-scale infilled steel frames, were performed by Flanagan and Bennett (1999) to investigate the IP/OOP interaction in URM infills. They showed that the main effect of IP damage is a reduction of the OOP stiffness. As a consequence, out-of-plane displacements are expected to be greater for damaged infills than for undamaged infills, especially under moderate levels of loading and/or high slenderness ratios. Further experimental studies (Pereira et al. 2011; Guidi et al. 2013; Hak et al. 2014) proved that also the OOP strength of URM infills can be significantly affected by the level of IP damage, especially for infill walls with high slenderness ratio. In addition, when IP/OOP loading is simultaneously applied, high vertical compression forces 
near the base of the wall can arise due to the combination of the thrust forces around the wall perimeter and the strut forces along the diagonal (Longo et al. 2018).

Recently, Ricci et al. (2018a, b) and De Risi et al. (2019) performed extensive experimental tests on 2/3-scaled infilled RC frame designed by the seismic Italian seismic Code (NTC2008). The scope of the tests was to investigate in-depth the effects of the IP/ OOP interaction and the influence of the slenderness ratio $(\mathrm{h} / \mathrm{t})$ on the OOP behavior of URM infills made with clay hollow bricks. URM infills with thickness equal to $80 \mathrm{~mm}$ $(\mathrm{h} / \mathrm{t}=22.9)$ and $120 \mathrm{~mm}(\mathrm{~h} / \mathrm{t}=15.2)$ were tested. Tests were carried out by applying outof-plane forces after attaining different levels of interstory drifts. A substantial reduction of both lateral stiffness and strength in the out-of-plane direction was observed, while increasing the drift level reached in the in-plane direction. For instance, for infills with slenderness ratio $\mathrm{h} / \mathrm{t}=22.9$, OOP strength reductions ranging from 25 to $70 \%$ were observed while increasing the drift level from 0.28 to $0.58 \%$. For infills with slenderness ratio $\mathrm{h} / \mathrm{t}=15.2$, a reduction of the OOP strength of the order of $40 \%$ was found for a drift level equal $0.89 \%$.

In summary, based on the outcomes of the experimental tests, the most critical variables affecting the OOP behavior of infill walls are the slenderness of the infill and the state of damage (e.g. maximum IDR) experienced by the wall in the IP direction. Although not directly addressed in the experimental tests, it is clear that also the restraint conditions with the RC frame and the storey of the building where the infill is located play a not negligible role towards the OOP performance of masonry infills.

In the last years, some researchers have started to develop a new generation of numerical macro-models, able to capture the IP/OOP interaction of URM infills subjected to seismic loading. Some authors derived IP/OOP interaction domains expressed in terms of forces or displacements. The IP/OOP interaction curves have been implemented in two different macro-models, featuring compression-only (Hashemi and Mosalam 2007) and tension-compression resisting (Kadysiewski and Mosalam 2009) diagonal truss elements, respectively. The OOP mass is lumped in the middle of the element. Mosalam and Günay (2015) developed a macro-model consisting of two elastic beam-with-hinges elements, placed along one diagonal and pinned to the surrounding RC frame. The IP/OOP behavior of the infill is governed by a bi-directional (IP axial load vs. OOP bending moment) domain. The effective mass of the infill is lumped in the midspan node to simulate OOP effects. Furtado et al. (2015b) proposed an equivalent bi-diagonal strut model where the IP/OOP interaction is defined assuming a linear interaction between IP and OOP ultimate displacement capacity. Di Trapani et al. (2018) calibrated a four-struts macro-element (for pushover analysis) comprising two diagonal fiber beam-column elements (simulating the IP behavior) plus one vertical and one horizontal fiber beam-column element (simulating the arching mechanism in the OOP direction), mutually connected in a node at the midspan. Recently, Di Domenico et al. (2017) proposed a new modelling approach for capturing the IP/OOP interaction in masonry infills. The modelling approach under consideration relies on suitable evolutive degradation relationships derived from experimental results and empirical observations (Ricci et al. 2018a, b), together with a specific algorithm for the removal of infills, as IP/OOP collapse occurs.

The main aim of this study is to investigate the influence of the IP/OOP interaction of URM infills on the seismic performance of typical residential RC buildings realized in Italy (and other European countries) in the second half of the last century. To this end, seven case studies are selected, differing in number of storeys and age of construction (hence structural details and infill characteristics). The modelling approach by Di Domenico et al. (2017), implemented within two sets of nonlinear zero-length link elements incorporated in a V-shaped bi-diagonal struts macro-element, is used to describe the IP/OOP interaction 
of masonry infills. Extensive Nonlinear response-Time History Analyses (NTHA) are carried out with OpenSees (McKenna et al. 2000), using nine sets of ground motion pairs, with increasing seismic intensity. For comparison, NTHA are carried out also neglecting the OOP response of the infills. Different building performance levels are then identified to examine the damage scenario experienced by the buildings, considering or neglecting the IP/OOP interaction for masonry infills. Based on results of this study, a set of fragility curves is tentatively proposed to express the probability of exceedance of the selected building performance levels as a function of the earthquake intensity level.

\section{Methodology of the study}

In this study, the influence of the IP/OOP behavior of URM infills in RC frame buildings subjected to seismic loading is investigated following a four steps methodology:

(i) Step 1: Selection of case-study; Modeling assumptions; Ground motion selection.

(ii) Step 2: Definition of seismic Performance Levels (PLs), based on a suitable multicriterion approach.

(iii) Step 3: Execution of NTHA.

(iv) Step 4: Derivation of fragility curves for different PLs, considering, or alternatively neglecting, the influence of the IP/OOP interaction for masonry infills.

\subsection{Case-study buildings}

Over the last decades, the design criteria and construction practice relevant to RC buildings have considerably changed. Table 1 identifies five classes of RC frame buildings, within the Italian RC buildings stock, as a function of the age of construction, design approach, and main structural/non-structural details. Herein, they are referred to as: (i) GLD: Gravity Load Design buildings, (ii) SSD: Sub Standard Design buildings, (iii) LSD: Low Seismic Design buildings, (iv) HSD: High Seismic Design buildings, and (v) MSD: Modern Standard Design buildings. Similar classifications also apply for other countries that feature similar construction practice.

In this paper, the attention is focused on three building classes only (namely GLD, SSD and HSD of Table 1), covering a wide spectrum of the current Italian building stock. Seven archetype buildings are considered: three for the SSD class and two for the GLD and HSD class, respectively. All the buildings feature the same plan and elevation configurations (see Fig. 1) while differing in the number of storeys (4-, 6- and 8-storeys) and location (the cities of L'Aquila and Napoli, respectively), besides age of construction and structural/non structural details (see Table 1). The selected buildings can be deemed to be representative of typical low-, medium- and high-rise multi-storeys residential buildings realized in Italy between 50's and 90's, which represent about $80 \%$ of the entire Italian RC building stock (ISTAT 2011).

The archetype buildings selected feature a rectangular plan with $27.30 \mathrm{~m} \times 15.30 \mathrm{~m}$ dimensions, and $3.00 \mathrm{~m}$ interstory height. The GLD buildings feature four frames in the long direction (X-direction in Fig. 1a) and two external frames in the short direction (Y-direction in Fig. 1a). The SSD and HSD buildings have six additional internal frames in the Y-direction. All the buildings have a central dog-leg stair with cantilever steps 
Table 1 Classification of Italian RC frame buildings

\begin{tabular}{|c|c|c|c|c|}
\hline Class* & Age (design standard)** & Design approach & Structural details & URM infills \\
\hline GLD & $\begin{array}{l}\text { Before } 1971 \\
\text { (R.D. 2229/1939) }\end{array}$ & Gravity loads only & $\begin{array}{l}\text { Frames in one direction } \\
\text { only } \\
\text { Plain rebar } \\
\text { Low strength concrete } \\
\text { No ductile seismic details }\end{array}$ & Double layers \\
\hline SSD & $\begin{array}{l}\text { 1971-1980 } \\
\text { (L. } 1086 / 71 ; \text { DM 1974) }\end{array}$ & Equivalent static forces & $\begin{array}{l}\text { Frames in one/both direc- } \\
\text { tions } \\
\text { Plain/deformed rebars } \\
\text { Low strength concrete } \\
\text { Internal flat beams } \\
\text { No ductile seismic details }\end{array}$ & Double layers \\
\hline LSD & $\begin{array}{l}\text { 1981-1995 } \\
\text { (DM 1986; DM 1992) }\end{array}$ & Equivalent static forces & $\begin{array}{l}\text { Frames in both directions } \\
\text { Deformed rebars } \\
\text { Internal flat beams } \\
\text { No ductile seismic details }\end{array}$ & Single layer \\
\hline HSD & $\begin{array}{l}\text { 1995-2003 } \\
\text { (DM 1996; OPCM 3274) }\end{array}$ & $\begin{array}{l}\text { Response spectrum } \\
\text { analysis }\end{array}$ & $\begin{array}{l}\text { Frames in both directions } \\
\text { Deformed rebars } \\
\text { Not mandatory ductile } \\
\text { seismic details }\end{array}$ & Single layer \\
\hline MSD & $\begin{array}{l}\text { After } 2003 \\
\text { (DM 2008; DM 2018) }\end{array}$ & $\begin{array}{l}\text { Response spectrum } \\
\text { analysis } \\
\text { +capacity design criteria }\end{array}$ & $\begin{array}{l}\text { Frames in both directions } \\
\text { Deformed rebars } \\
\text { Mandatory ductile seismic } \\
\text { details }\end{array}$ & Single layer \\
\hline
\end{tabular}

*GLD: Gravity load design; SSD: Substandard Seismic Design; LSD: Low Seismic Design; HSD: High Seismic Design; MSD: Modern Standard Design

**For more information see https://www.ingegneriasismicaitaliana.com/it/24/normative/

sustained by two stiff 'knee' beams in the Y-dir. Floors are assumed to be realized by oneway concrete slabs with $240 \mathrm{~mm}$ total thickness.

Structural characteristics (including cross sections of RC columns and beams, reinforcement ratios, etc.) have been derived from a simulated design, in accordance with the technical standards and design rules in force in Italy at that time, adopting the Allowable Stress design method for the GLD and SSD buildings while the Limit State design method for the HSD buildings. For the buildings located in L'Aquila seismic forces have been computed considering a seismic coefficient $(\mathrm{C})$ equal to 0.07 (medium seismic-risk region) and a typical subsoil class and structural behavior $(\mathrm{R}=\varepsilon=\beta=1)$.

Gravity loads are represented by a dead load of $4.00 \mathrm{KN} / \mathrm{m}^{2}$ on the top floor and 5.50 $\mathrm{KN} / \mathrm{m}^{2}$ on the other floors, and a live load of $2.0 \mathrm{KN} / \mathrm{m}^{2}$ for all the floors. An average weight per volume unit of $8.50 \mathrm{KN} / \mathrm{m}^{3}$ has been considered for masonry infills.

The simulated design of the GLD buildings has been carried out assuming an allowable stress equal to $5.0 \mathrm{~N} / \mathrm{mm}^{2}$ for concrete and $140 \mathrm{~N} / \mathrm{mm}^{2}$ for steel (Aq42 plain steel rebars), in line with the Italian Royal Decree 2229/1939. For the SSD and HSD buildings, a concrete characteristic compressive strength of $25 \mathrm{MPa}$ and a steel characteristic yield strength of $430 \mathrm{MPa}$ (FeB44K deformed steel rebars) have been assumed, corresponding to an allowable stress of 8.5 and $260 \mathrm{MPa}$, respectively.

Cross section dimensions of beams and columns, derived from simulated design, are reported in Table 2. As can be seen, the cross-section size of RC columns varies in the 


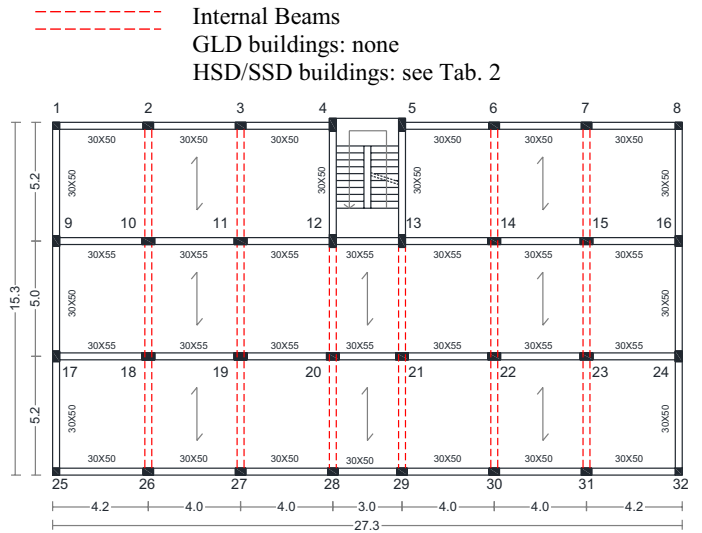

(a)

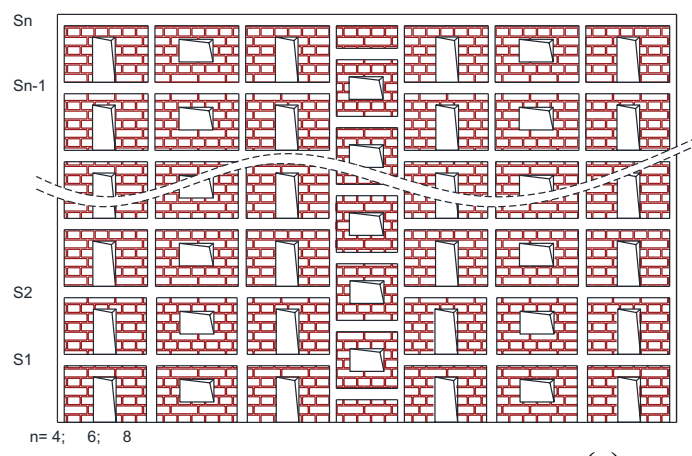

GLD/SSD buildings HSD buildings

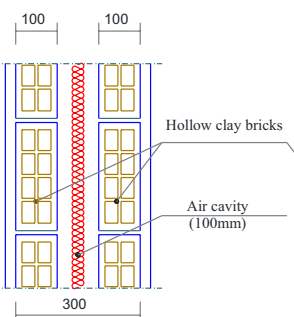

(b)
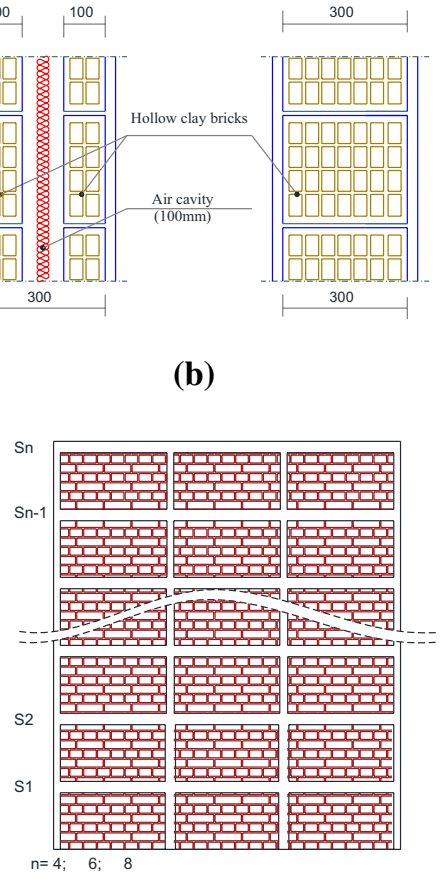

(c)

Fig. 1 Selected case-study buildings: a plan view, b masonry infills configuration and $\mathbf{c}$ lateral views

range of $300 \times 650-300 \times 300 \mathrm{~mm}$, depending on the number of floors of the building. For all building types, the cross sections of the RC columns taper by $100 \mathrm{~mm}$ every two floors, except the columns at the corners of the building and those around the staircase, which present a constant cross section $(300 \times 300 \mathrm{~mm}$ and $300 \times 500-300 \times 650 \mathrm{~mm}$, respectively) along the entire building height. RC beams located around the perimeter of the building, and around the staircase, have $300 \times 500 \mathrm{~mm}$ cross section. The main difference between HSD and SSD buildings is the presence of internal $300 \times 400 \mathrm{~mm}$ exposed beams (LSD buildings) instead of $600 \times 240 \mathrm{~mm}$ flat beams (SSD buildings).

For the GLD buildings, the longitudinal reinforcement is realized with $14 \mathrm{~mm}$ diameter plain bars with end hooks at the ends; $6 \mathrm{~mm}$ diameter stirrups are considered as transverse reinforcement. For the SSD and HSD buildings, the longitudinal reinforcement is realized with $16 \mathrm{~mm}$ (beams) and $18 \mathrm{~mm}$ (columns) deformed bars; $8 \mathrm{~mm}$ diameter stirrups are considered as transverse reinforcement. Longitudinal reinforcement ratios and stirrups spacing are reported in Table 2 for each building model.

For GLD and SSD buildings, masonry infills are realized with hollow clay bricks arranged in two layers with $100 \mathrm{~mm}$ thickness each, separated by an air cavity of $100 \mathrm{~mm}$, in line with the construction practice of that time. For the HSD buildings, masonry infills are characterized by a single layer of hollow clay bricks with $300 \mathrm{~mm}$ thickness. In both 


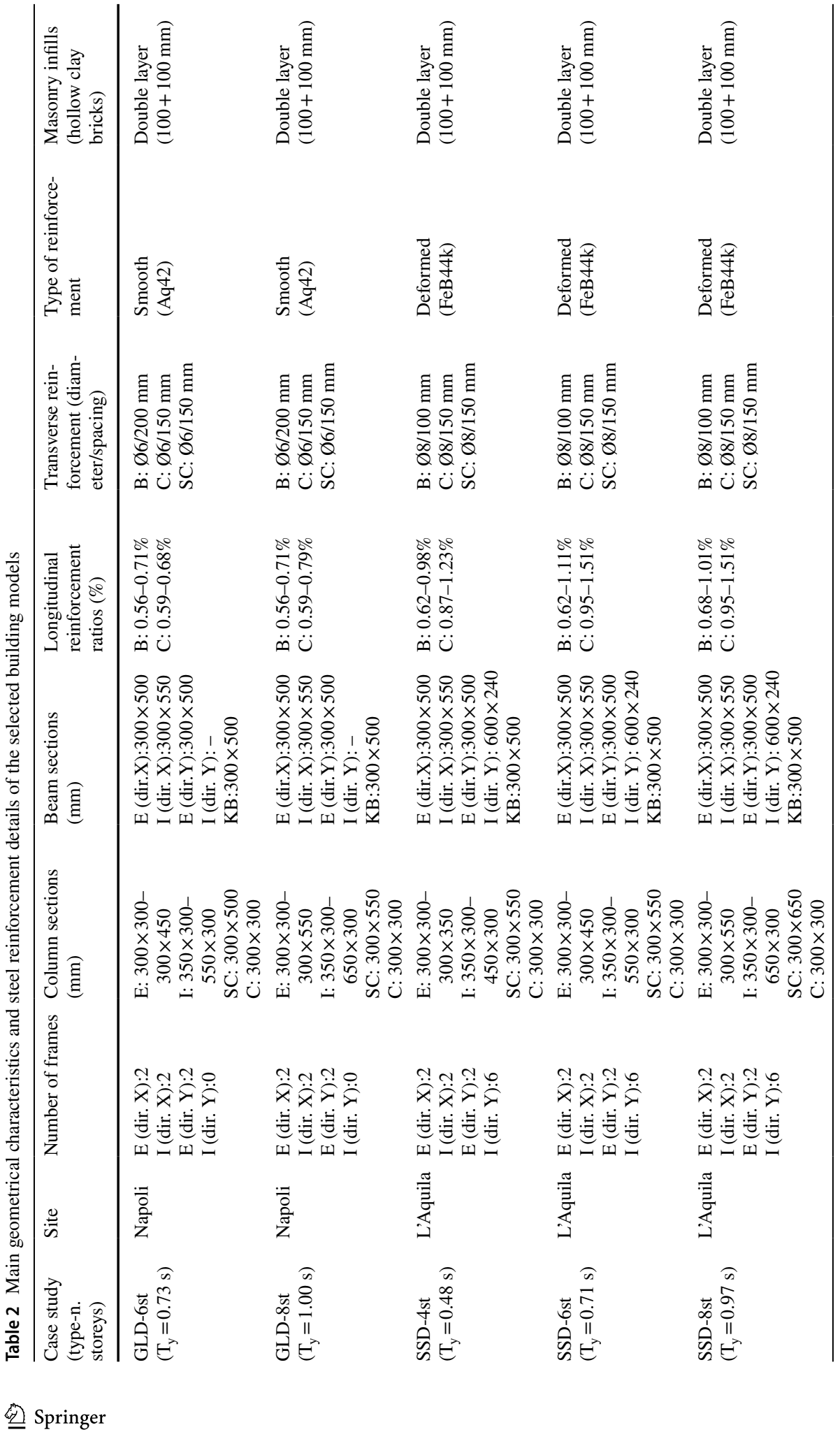




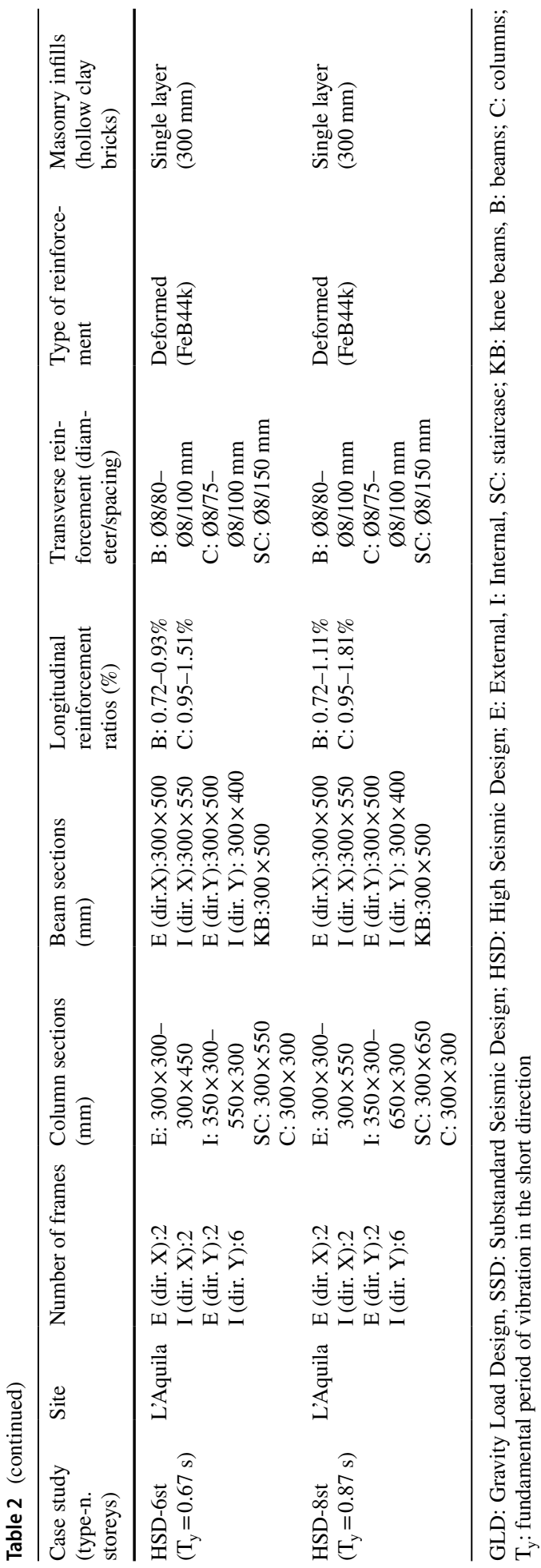


cases, the holes of the bricks are arranged in the horizontal direction. For all building configurations, masonry infills located in the long direction (X-dir.) feature large opening while those placed in the short direction ( $\mathrm{Y}$ dir.) have no openings. In this study, the attention is focused on masonry infills without openings only, the influence of masonry infills with (large) openings being relatively low towards the seismic behavior of the building. Therefore, for simplicity, their contribution has been neglected in the structural model.

The fundamental periods of vibration in the short direction $\left(\mathrm{T}_{\mathrm{y}}\right)$ of each building model, derived from modal analysis, are listed in Table 2.

\subsection{Ground motion selection}

The case-study buildings are supposed to be located in the city of L'Aquila (SSD and HSD buildings) and in the city of Napoli (GLD buildings), respectively, both on soil type C (soft soil), according to the current Italian code classification. It is worth noting that the city of L'Aquila was classified as second seismic category/class (medium level of seismic hazard for Italy) from 1915. The city of Napoli, instead, was classified as seismic area for the first time only in the 1981 (third seismic category/class). According to the current seismic hazard map of Italy, the city of L'Aquila represents one of the city with the highest level of seismicity in Italy with a design earthquake intensity level with 475 years return period of $0.35 \mathrm{~g}$ for soil type $\mathrm{C}$ and $0.47 \mathrm{~g}$ with 2475 year return period, again for soil type $\mathrm{C}$. The city of Napoli features a medium level of seismic hazard with a design earthquake intensity level with 475 years return period of $0.25 \mathrm{~g}$ for soil type $\mathrm{C}$ and $0.35 \mathrm{~g}$ with 2475 years return period, again for soil type $\mathrm{C}$.

Table 3 compares the earthquake hazard of L'Aquila and Napoli in terms of spectral acceleration for three values of conditioning period, namely: $\mathrm{T}^{*}=0.50 \mathrm{~s}, 0.75 \mathrm{~s}$ and $1.0 \mathrm{~s}$, corresponding approximately to the average (in the two orthogonal directions) of the effective fundamental periods of the 4-, 6- and 8-storeys buildings, respectively. Nine earthquake intensity levels, with return periods (Tr) ranging from 30 to 2475 years, have been derived from the hazard curve provided by the Italian Institute of Geophysics and Vulcanology (INGV). Moreover, for a better understanding of the phenomena, an additional seismic intensity level, with return period equal to 5000 years, has been considered for NTHA. The latter has been extrapolated based on best fit to the hazard curve, using a second-order polynomial law in log space, as proposed by Vamvatsikos (2014).

For each earthquake intensity level, NTHA have been performed using a set of 10 ground motion pairs selected and scaled by Ay et al. (2017), in such a way to be compatible with suitable Conditional Mean Spectra (CMS) (Baker 2011), derived considering an appropriate $\mathrm{M}-\mathrm{R}-\varepsilon$ (magnitude-distance-epsilon) disaggregation and a suitable attenuation relationship for each building site. The values of $\mathrm{T}^{*}$ shown in Table 3 have been used as conditioning periods for the derivation of the CMS. As an example, Fig. 2 compares the $5 \%$-damping reference spectrum with the average response spectrum derived from the set of selected ground motions for the city of Napoli (Fig. 2a) and L'Aquila (Fig. 2b), respectively, for an earthquake intensity level with $T_{R}=2500$ years return period and conditioning period $\mathrm{T}^{*}=0.75 \mathrm{~s}$. 
Table 3 Earthquake intensity levels considered for the building models under scrutiny

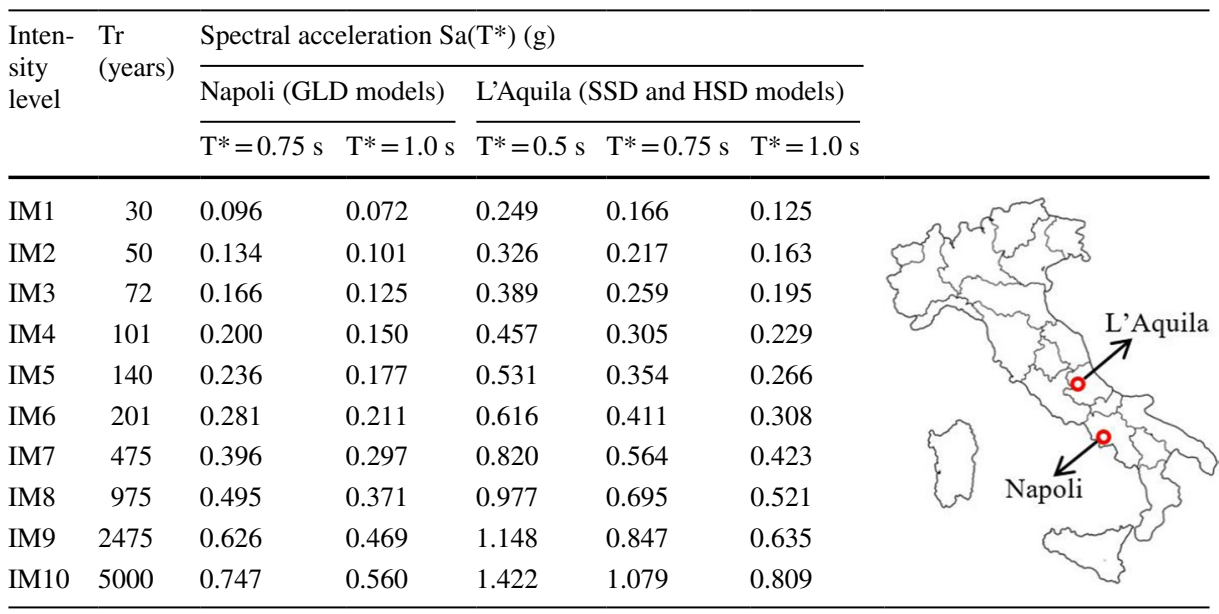

$\mathrm{T}^{*}$ : average fundamental periods (in the two orthogonal directions) of the building model

\subsection{Numerical model}

A refined 3D lumped-plasticity model has been implemented in OpenSees (McKenna et al. 2000) for each case-study building. Beam-with-hinges elements have been used to describe the mechanical behavior of RC members, based on given constitutive laws for steel (see Fig. 3a) and concrete (see Fig. 3b).

For RC members with plain rebars (ref. to GLD models) bar slipping effects have been captured by using a modified constitutive law for steel rebars (see Fig. 3a), in accordance with (Braga et al. 2012), and neglecting the contribution of compression longitudinal rebars, in accordance with evidence from past studies (e.g., Calvi et al. 2002; Fabbrocino et al. 2004). Concrete confinement has been neglected (see Fig. 3c), due to the low effectiveness of stirrups in old buildings. In addition, a reduced plastic hinge length (equal to H/3 for beams and H/4 for base columns, see Cardone and Perrone 2015) has been assumed, to take into account that flexural cracks do not spread along the element during repeated cyclic deformation, while their width increases significantly due to bond slip effect.

Plastic hinges (see Fig. 3c) are characterized by a tri-linear cyclic hysteretic behavior, described by the modified Ibarra-Medina-Krawinkler deterioration model (Ibarra et al. 2005). The yielding $\left(M_{y}\right)$ and ultimate bending moment $\left(M_{u}\right)$ (see Fig. 3c) have been derived by an accurate moment-curvature analysis on fiber sections characterized by suitable constitutive laws of materials (see Fig. 3). The yielding $\left(\theta_{\mathrm{y}}\right)$ and ultimate chord rotation $\left(\theta_{\mathrm{u}}\right)$ have been evaluated using the formula reported in Verderame et al. (2001a, b) to take into account the poor bond capacity of plain bars. As far as the post cappingrotation capacity $\left(\theta_{\mathrm{c}}-\theta_{\mathrm{u}}\right)$ is concerned, reference to the relationship proposed by Ibarra et al. (2005) has been made. The plastic hinges of the short columns around the stairs 


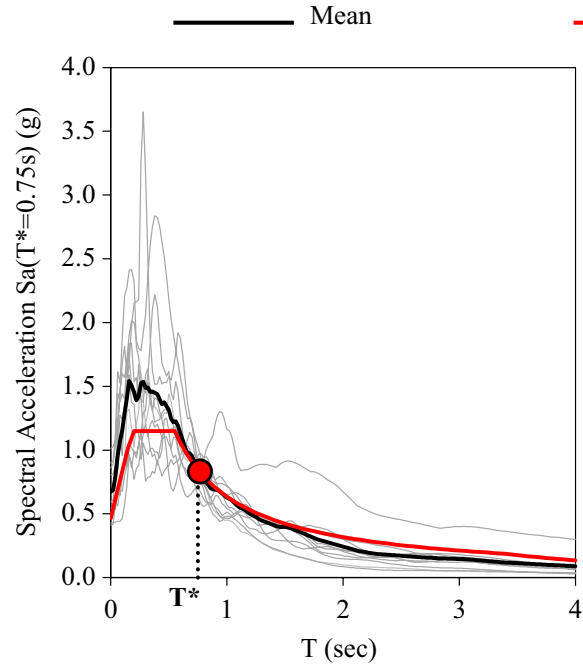

(a)

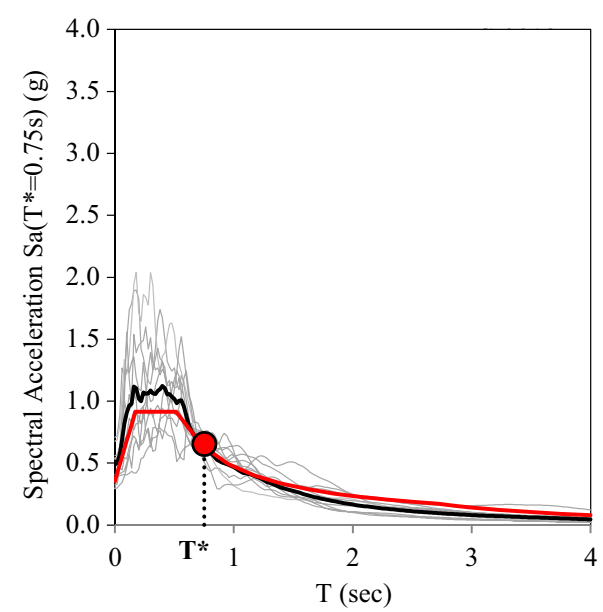

(b)

Fig. 2 Comparison between code-conforming reference spectrum and average response spectrum of the selected ground motions $\left(\mathrm{T}^{*}=0.75 \mathrm{~s}, \mathrm{Tr}=2475\right.$ years, soil C) for a L'Aquila and $\mathbf{b}$ Napoli

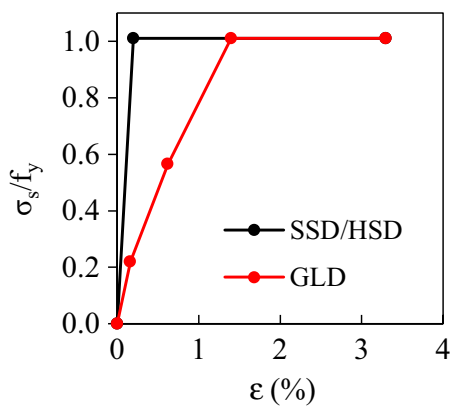

(a)

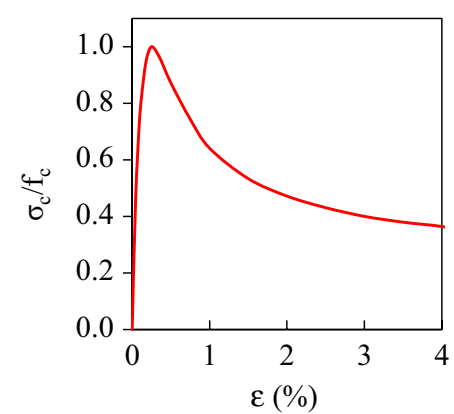

(b)

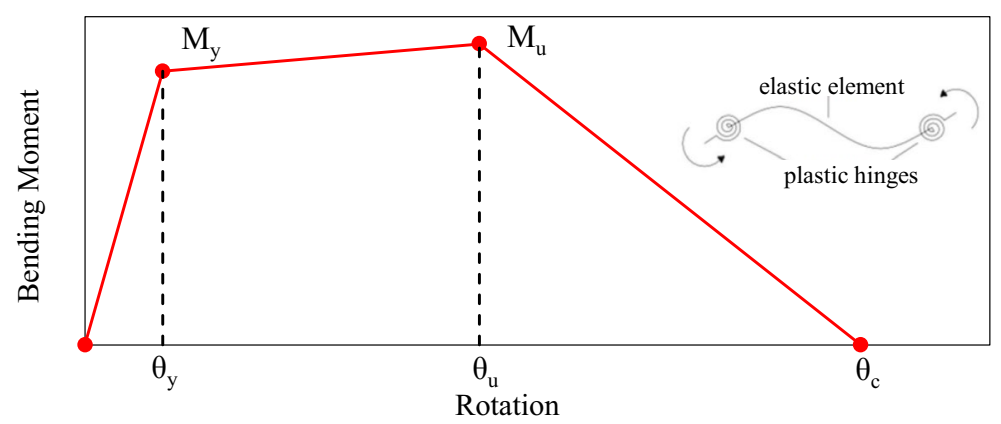

(c)

Fig. 3 Constitutive law of $\mathbf{a}$ steel and $\mathbf{b}$ not-confined concrete and $\mathbf{c}$ tri-linear moment-rotation curve adopted for plastic hinges 
have been modified to capture the potential brittle failure of such elements, considering the shear strength formulation proposed by Sezen and Moehle (2004).

As far as the strength of materials is concerned, reference to the experimental results reported in Verderame et al. (2001a, b) has been made, assuming a concrete compression strength of $25 \mathrm{MPa}$ for GLD buildings and $28 \mathrm{MPa}$ for SSD/LSD buildings, respectively, and a steel yield strength of $325 \mathrm{MPa}$ for GLD buildings and $430 \mathrm{MPa}$ for SSD/ HSD buildings, respectively.

More details on the modeling assumptions for RC members can be found in Cardone and Perrone (2017).

URM infills have been modelled with a V-shaped bi-diagonal strut macro-element incorporating two sets of nonlinear zero-length link elements lumped in the central node (see Fig. 4). The modeling approach proposed by Di Domenico et al. (2017) has been implemented to account for the IP/OOP interaction of masonry infills. The modeling strategy under consideration consists of three main steps:

(i) Definition of the skeleton curves representing the IP and OOP undamaged behavior of masonry infills;

(ii) Use of semi-empirical relationships to derive a number ("n") of degraded (damaged) backbone curves from the relevant undamaged counterpart, as a function of the Intersorey Drift Ratio (IDR) (OOP degraded curves) and OOP displacements (IP degraded curves), respectively;

(iii) Implementation of the " $n+1$ " IP and OOP backbone curves within the selected macro-model using an appropriate routine, that removes masonry infills from the building model, during NTHA, when either IP or OOP collapse occurs (attainment of the ultimate displacement, see Fig. 5).

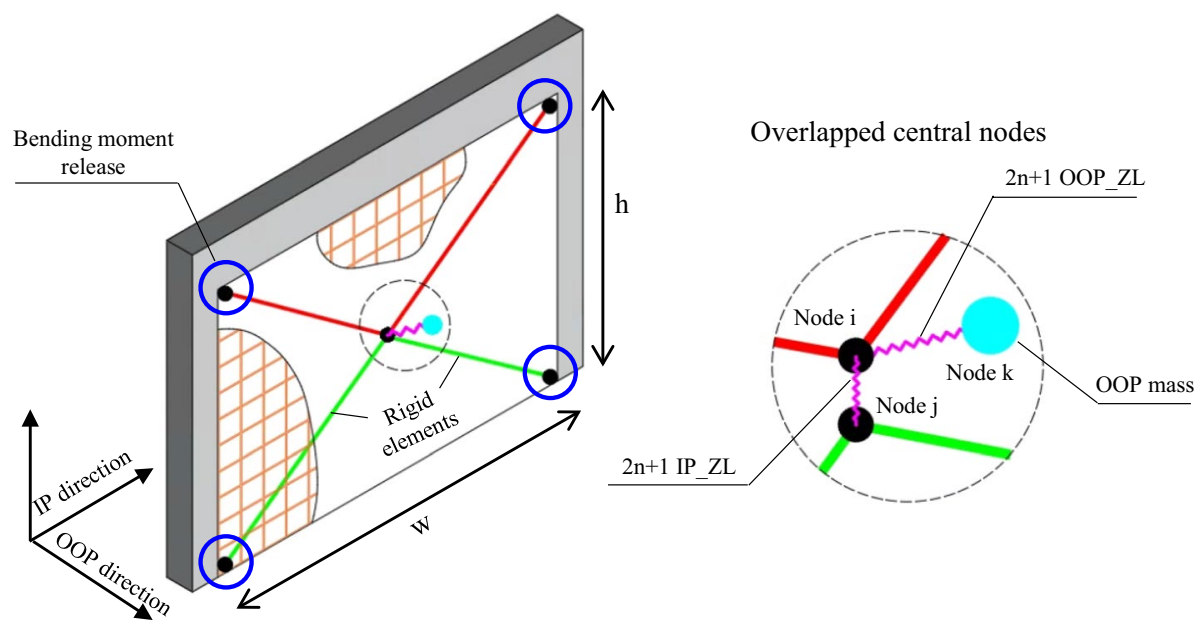

Fig. 4 Schematic representation of the macro-model used for URM infills 


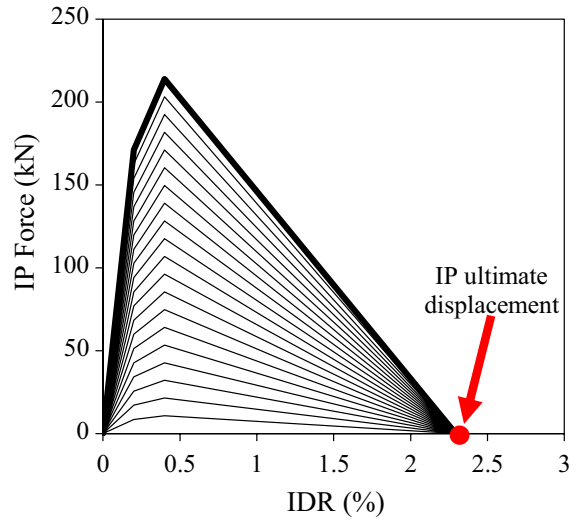

(a)

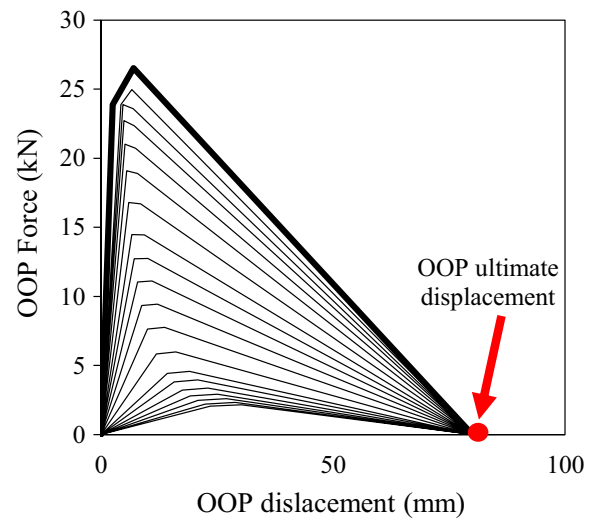

(b)

Fig. 5 a IP and b OOP backbone curves adopted for the double-layer infills $(100+100 \mathrm{~mm}$ thickness $)$

Figure 5 shows the two groups of " $n+1$ " tri-linear curves adopted in this study to describe the IP/OOP degrading behavior of double-layer infills $(100+100 \mathrm{~mm})$, where " $\mathrm{n}$ " has been set equal to 19 in order to get accurate results.

The undamaged IP behavior of the infills has been modeled using the tri-linear skeleton curve proposed in Sassun et al. (2016), assuming a compressive strength in the vertical direction $\left(f_{\mathrm{mv}}\right)$ of $1.2 \mathrm{MPa}$, a shear strength $(\tau)$ of $0.3 \mathrm{MPa}$, and an elastic modulus in the vertical direction $\left(\mathrm{E}_{\mathrm{mv}}\right)$ of $1050 \mathrm{MPa}$, respectively, in accordance with Decanini et al. (2004).

Moreover, a compression strength in the horizontal direction ( $\left.\mathrm{f}_{\mathrm{mh}}\right)$ equal to $2.6 \mathrm{MPa}$ and an elastic modulus in the horizontal direction $\left(\mathrm{E}_{\mathrm{mh}}\right)$ of $1960 \mathrm{MPa}$, corresponding to the average values of the experimental data reported in Table 4, have been assumed.

In this sttudy, a set of semi-empirical relationships has been derived to define the undamaged OOP behavior of the infills, as a function of a number of geometric (thickness " $t$ ", height "h" and width "w") and mechanical $\left(f_{m v}, f_{m h}, E_{m v}, E_{m h}\right)$ parameters. To this end, five OOP pseudo-static tests have been considered for the double-layers $(100+100 \mathrm{~mm})$ infills of GLD/ SSD buildings (see Table 4), whose results have been processed following a linear leastsquares regression analysis.

The relationships thus obtained are reported in Eqs. (1)-(3), which provide: (i) the cracking force $F_{\text {crack }}$, (ii) the secant stiffness $K_{\text {crack }}$ and (iii) the peak force $F_{\max }$, respectively. In Table 5, the values of the coefficients $a_{1}, a_{2}$, and $a_{3}$ (see Eq. (1)), $b_{1}$ and $b_{2}$ (see Eq. (2)) and $\theta_{1 v}, \theta_{2 v}, \theta_{3 v}$, $\theta_{1 \mathrm{~h}}, \theta_{2 \mathrm{~h}}, \theta_{3 \mathrm{~h}}$ (see Eq. (3)) are reported.

$$
\begin{gathered}
F_{\text {crack }}=\min \left(0.9 F_{\text {max }} ; a_{1} f_{m v}^{a_{2}}\left(\frac{t}{h}\right)^{a_{3}} w h\right) \\
K_{\text {crack }}=\frac{1}{12\left(\left(\frac{t}{h}\right)^{b_{1}}\left(\frac{w}{h}\right)^{b_{2}}\right)\left(1-v^{2}\right)} \frac{E_{m v} w}{\left(\frac{h}{t}\right)^{3}} \\
F_{\text {max }}=\left[\theta_{1 v} f_{m v}^{\theta_{2 v}}\left(\frac{t}{h}\right)^{\theta_{3 v}}+\theta_{1 h} f_{m h}^{\theta_{2 h}}\left(\frac{t}{w}\right)^{\theta_{3 h}}\right] w h
\end{gathered}
$$




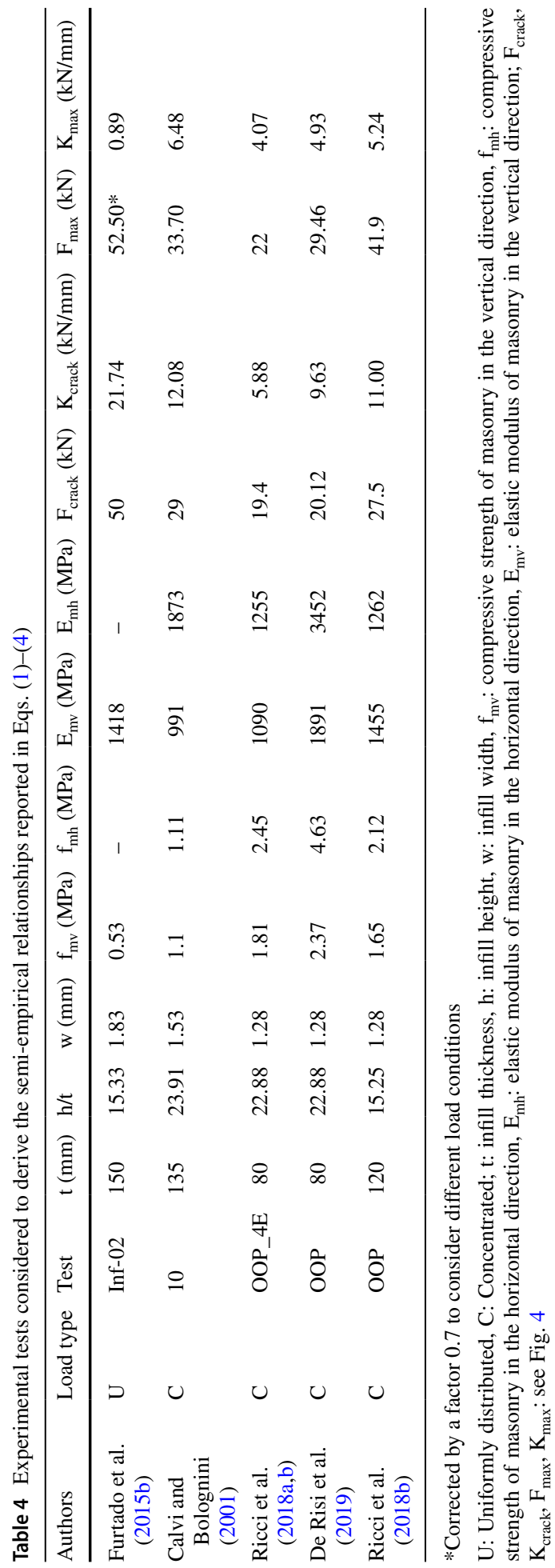


Table 5 Values of the coefficients of Eqs. (1)-(3)

\begin{tabular}{lllllllllll}
\hline $\mathrm{a}_{1}$ & $\mathrm{a}_{2}$ & $\mathrm{a}_{3}$ & $\mathrm{~b}_{1}$ & $\mathrm{~b}_{2}$ & $\theta_{1 \mathrm{v}}$ & $\theta_{2 \mathrm{v}}$ & $\theta_{3 \mathrm{v}}$ & $\theta_{1 \mathrm{~h}}$ & $\theta_{2 \mathrm{~h}}$ & $\theta_{3 \mathrm{~h}}$ \\
\hline 0.75 & 0.35 & 1.75 & 1.82 & 0.15 & 5.2 & 0.15 & 2.53 & 0.55 & 0.84 & 1.80
\end{tabular}

It is worth noting that the semi-empirical relationships (1) and (3) are similar to the expressions proposed in the Eurocode 6 (2005) for the evaluation of the lateral strength of masonry walls. Equation (2), instead, has been derived by the Timoshenko's theory applied to an elastic isotropic plate hinged along the border, replacing the analytical coefficient with the term $\left[(\mathrm{t} / \mathrm{h})^{\mathrm{b} 1} *(\mathrm{w} / \mathrm{h})^{\mathrm{b} 2}\right]$. In Fig. 6 the experimental values of $\mathrm{F}_{\text {crack }}, \mathrm{K}_{\text {crack }}$ and $\mathrm{F}_{\text {max }}$ listed in Table 5 are compared to those predicted using Eqs. (1), (2) and (3), respectively.

The secant stiffness at the peak strength $\left(\mathrm{K}_{\max }\right)$ has been assumed equal to:

$$
K_{\max }=0.40 \cdot K_{\text {crack }}
$$

based on the average values of the stiffness ratio $\mathrm{K}_{\max } / \mathrm{K}_{\text {crack }}$ obtained from experimental tests (see Table 5). Finally, the OOP ultimate displacement capacity $\left(\mathrm{d}_{\mathrm{OOP}}\right)$ has been assumed equal to $80 \%$ the infill thickness, in accordance with Angel et al. (1994).

In first approximation, the same relationships (ref. to Eqs. (1)-(4)) have been used to characterize also the OOP behavior of the $300 \mathrm{~mm}$ thickness single-layer infills.

The jump from one skeleton curve to another is governed by the semi-empirical relationships proposed in Ricci et al. (2018b), which provide the reduction of OOP stiffness and OOP strength as a function of IP damage (and vice versa).

The IP and OOP skeleton curves thus derived have been implemented in OpenSees (McKenna et al. 2000) within the V-shaped bi-diagonal strut macro-element shown in Fig. 4. The equivalent struts feature suitable bending moment releases at the ends close to the $\mathrm{RC}$ beam-column joints. The $\mathrm{V}$-shaped bi-diagonal struts are connected by two sets of $2 n+1$ zero-length nonlinear link elements reproducing the IP degrading cyclic behavior of the infill. To avoid any lability, an "Equal" type constrain is assigned to the two overlapped nodes of the V-shaped struts (see node "i" and "j" in Fig. 4) in the OOP

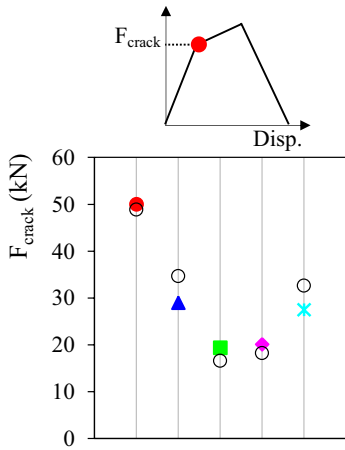

(a)

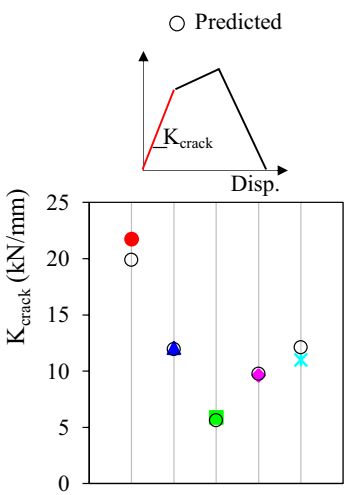

(b)

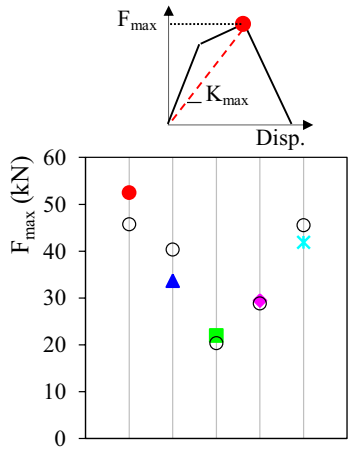

(c)

Fig. 6 Comparison between experimental data and values derived from the proposed semi-empirical relationships: a cracking force, $\mathbf{b}$ cracking stiffness, $\mathbf{c}$ peak force 
direction. An additional node with lumped mass equal to the effective mass of the infill (herein taken equal to $80 \%$ of the infill total mass, in accordance with (Kadysiewski and Mosalam 2009)) is implemented in the middle of the element (see Fig. 4). The auxiliary node is linked to the equivalent struts by $2 n+1$ zero-length nonlinear link elements reproducing the OOP degrading cyclic behavior of the infill. A specific algorithm is used to remove the infill from the structural model when the ultimate IP/OOP displacement is reached.

The hysteretic cyclic behavior of the infills has been captured by the Hysteretic Material rule implemented in OpenSees, in which the stiffness cyclic degradation is described by the so-called $\beta$ coefficient. In this study, the $\beta$ coefficient has been set equal to 0.8 , in line with experimental results reported by Hak et al. (2014) and Furtado et al. (2015b). The pinching factors $\mathrm{p}_{\mathrm{x}}$ and $\mathrm{p}_{\mathrm{y}}$, governing the deformation and force behavior during cyclic loading have been taken equal to 0.8 and 0.20 , respectively, for the IP cyclic behavior, while equal to 1.0 for the OOP cyclic behavior.

It should be noted that all the relationships used in this study have been defined based on a number of experimental pseudo-static tests on different infill specimens, featuring: (i) different units (solid bricks, hollows bricks) and infill materials (clay, concrete), (iii) scale specimens (full- or reduced-scale), (iv) frame-types (steel, RC) and (v) load configurations (uniform, concentrated, linear). Furthermore, a linear least-squares regression analysis has been used to correlate the experimental parameters (IP/OOP force, secant stiffness, cracking, peak strength and ultimate displacements, etc.) with a number of geometric and mechanical characteristics of the infill (thickness, height, elastic modulus, compressive strength, etc.). It is then clear that the semi-empirical relationships adopted are affected by a number of epistemological uncertainties associated with the difficulty in reproducing the real working conditions of the infills during seismic events and the influence of the statistical process adopted that involves modeling and analyses of several independent variables that are included, all together, in the final proposed relationship. These uncertainties (together with other sources of uncertainties discussed in the next paragraphs) have been taken into account by considering additional dispersion factors $(\beta)$ in the derivation of fragility curves (see paragraph 5.).

\section{Definition of performance levels}

Three Performance Levels (PLs), associated with different post-earthquake damage scenarios, have been identified in this study. They are referred to as: (i) Usability Preventing Damage (UPD) performance level, (ii) Life Safety (LS) performance level and (iii) Global Collapse (GC) performance level, respectively. The description of each PL, in terms of expected post-earthquake damage scenario is reported in Table 6. In the same table the multi-criteria approach adopted to define the threshold limits of each PL are summarized.

It's worth noting that the definition of PLs adopted in this study was purposely done to reduce the computational efforts required to process NTHA results at the level of individual elements. However, it is fully reasonable and compatible with the scope of the paper.

The UPD performance level has been defined following a multi-criterion approach (Cardone et al. 2017; Perrone et al. 2019) based on the following three conditions (whichever occurs first): 


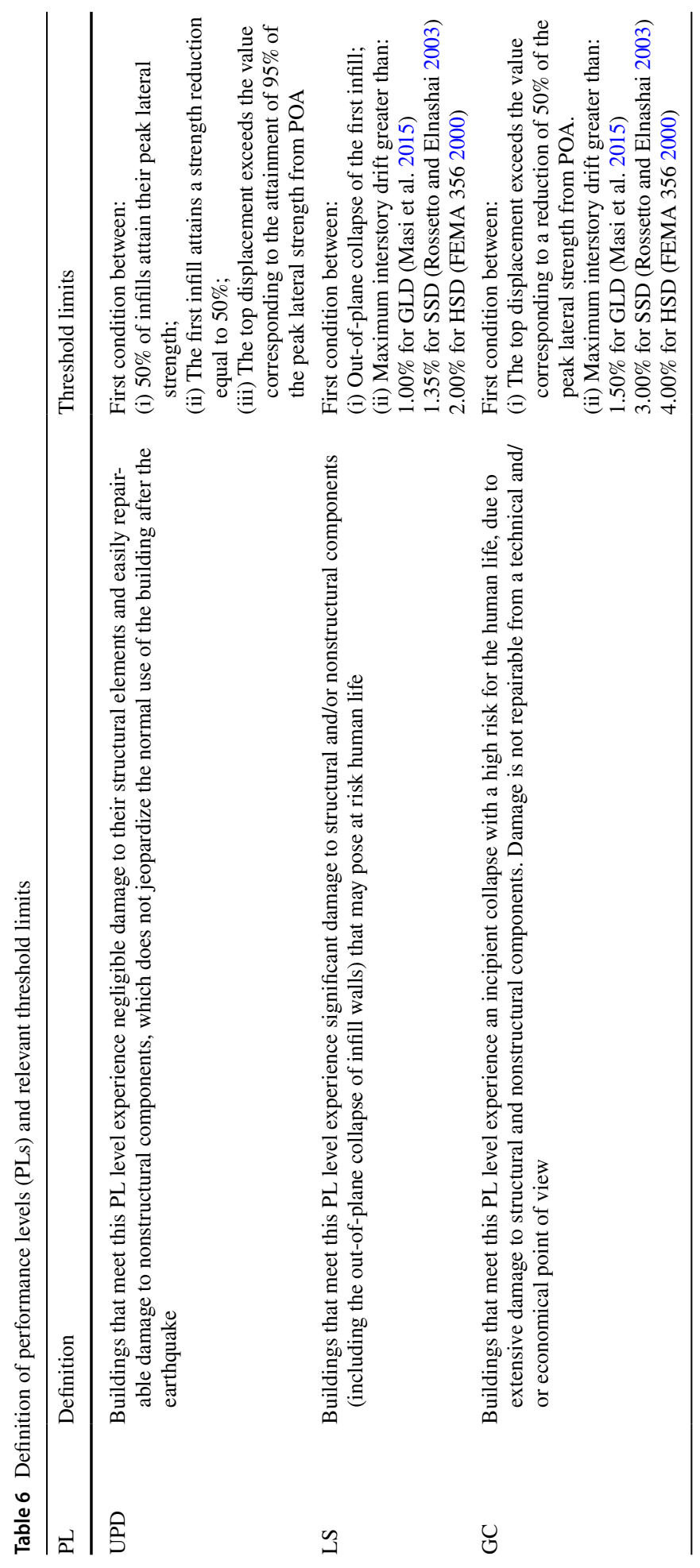


(i) Extensive damage of many infills: attainment of the peak lateral strength in more than $50 \%$ of the infills, for interstory drifts greater than $0.40 \%$, in accordance with the definition of DS2 damage state reported in Cardone and Perrone (2015);

(ii) Severe damage of the first infill: strength reduction greater than $50 \%$ of the first infill, for interstory drifts greater than $1.4 \%$, in accordance with the definition of DS3 damage state reported in Cardone and Perrone (2015), corresponding to a not-repairable condition of the infill;

(iii) Onset of structural damage requiring some repair interventions: the top displacement from NTHA exceeds the value corresponding to the attainment of $95 \%$ the peak lateral strength (the force level before the peak) from PushOver Analysis (POA).

The LS performance level has been defined following a different multi-criterion approach that includes:

(i) Out-of-plane collapse of the first infill;

(ii) Exceedance of a given interstory drift limit, corresponding to the attainment of a LS performance level in the main structure. The drift limit under consideration has been assumed equal to $1.00 \%$ for GLD buildings [in accordance with Masi et al. (2015)], $1.35 \%$ for SSD buildings [in accordance with Rossetto and Elnashai (2003)] and $2.00 \%$ for HSD buildings [in accordance with FEMA 356 (2000)].

The IP collapse of the infill does not affect the LS performance level, because it always occurs for drift levels greater than the assumed drift limits. Obviously, when the out-ofplane collapse of one infill takes place before extensive/severe in-plane damage of the infills, LS and UPD coincide.

Finally, the GC performance level has been defined considering the lowest between the following displacement limits:

(i) The top displacement corresponding to a $50 \%$ reduction of the lateral strength of the RC frame (i.e. 50\% reduction of the shear forces in the RC columns of the first storey) from POA;

(ii) The interstory drift limit associated with the attainment of a GC performance level for the main structure. The drift limit under consideration has been assumed equal to $1.50 \%$ for GLD buildings [in accordance with Masi et al. (2015)], 3.00\% for SSD buildings [in accordance with Rossetto and Elnashai 2003] and 4.00\% for HSD buildings [in accordance with FEMA 356 (2000)].

\section{Structural response}

For each case study, a Push-Over Analysis (POA) in the short direction of the building (see Fig. 1a) has been carried out with Opensees, considering, alternatively, a linear and an uniform force distribution along the height of the building, concentrated in the center of mass of each floor. Obviously, during POA, the behavior of the infills is governed by the first (undamaged) IP backbone curve only (see Fig. 5).

As an example, Fig. 7a shows the capacity curves derived from POA for the 8-storey GLD building, plotted in terms of base shear $\left(\mathrm{V}_{\mathrm{b}}\right)$ versus top floor displacement $\left(\mathrm{d}_{\text {top }}\right)$. In the same figure, the points corresponding to the attainment of $95 \%$ of the peak lateral 


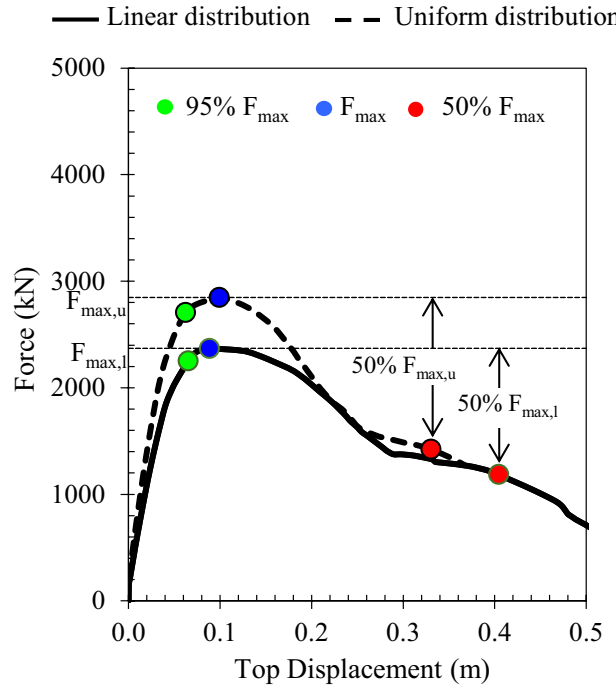

(a)

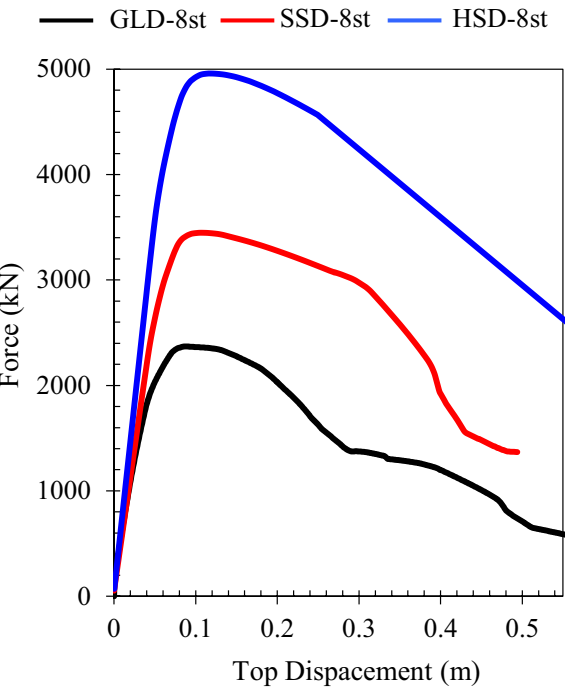

(b)

Fig. 7 a Comparison between capacity curves derived using uniform and linear distribution for the GLD8st, b capacity curves of the GLD-8st, SSD-8st and HSD-8st building models

strength (the force level before the peak) and strength reduction of 50\% are also reported. Such values are used in the definition of the UPD and GC performance levels, respectively, as discussed before (see Table 4). Figure $7 \mathrm{~b}$ compares the capacity curves of the three 8-storey buildings (linear force distributions). As expected, older buildings experience lower values of strength and initial stiffness $\left(\mathrm{K}_{\mathrm{in}}\right)$ with a more pronounced strength reduction after the peak.

Differences in terms of $\mathrm{K}_{\text {in }}$ are certainly due to the presence of stronger infills $(\mathrm{t}=300 \mathrm{~mm})$ for the HSD model (compared to the SSD model) and to the presence of internal frames in the short direction for the SSD model (compared to the GLD model).

Table 7 summarizes the main results derived from POA, expressed in terms of (i) initial stiffness $\left(\mathrm{K}_{\mathrm{in}}\right)$ (ii) maximum strength $\left(\mathrm{V}_{\mathrm{b}, \max }\right)$ normalized by the weight $(\mathrm{W})$ of the building, (iii) top displacement corresponding to $95 \%$ of the peak lateral strength $\left(\mathrm{d}_{\text {top95个}}\right)$ and (iv) top displacement corresponding to $50 \%$ reduction of the peak strength $\left(\mathrm{d}_{\text {top50 } \downarrow}\right)$. The values reported in Table 5 represent the lowest values from POA

Table 7 Main results derived from pushover analysis of the selected case studies

\begin{tabular}{|c|c|c|c|c|}
\hline Case study & $\mathrm{K}_{\mathrm{ini}}(\mathrm{kN} / \mathrm{m})$ & $\mathrm{V}_{\mathrm{b}, \max } / \mathrm{W}$ & $\mathrm{d}_{\mathrm{top} 95 \uparrow}(\mathrm{mm})$ & 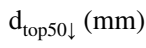 \\
\hline GLD-6st & 66,667 & 0.107 & 51 & 217 \\
\hline GLD-8st & 52,667 & 0.076 & 65 & 398 \\
\hline SSD-4st & 100,020 & 0.252 & 50 & 189 \\
\hline SSD-6st & 70,000 & 0.158 & 58 & 357 \\
\hline SSD-8st & 55,667 & 0.111 & 75 & 426 \\
\hline HSD-6st & 91,667 & 0.207 & 63 & 378 \\
\hline HSD-8st & 76,667 & 0.160 & 81 & 518 \\
\hline
\end{tabular}


considering linear and uniform force distributions. As expected (Cardone 2007), higher values of $\mathrm{V}_{\mathrm{b}, \max } / \mathrm{W}, \mathrm{d}_{\text {top } 95 \uparrow}$ and $\mathrm{d}_{\text {top50 }}$ are found for modern buildings (featuring higher seismic standards). The strength ratios $\left(\mathrm{V}_{\mathrm{b}, \max } / \mathrm{W}\right)$ increases while decreasing the number of storeys of the building.

\subsection{Interstory drift profiles}

Figure 8 shows some typical maximum IDR profiles (average values over 10 ground motion pairs) derived from NTHA for the SSD-6st building model, at three different seismic intensities (i.e. IM6, IM8 and IM10).

As can be seen, the IDR profiles feature a marked bulged shape with higher values at the mid-lower storeys of the building, which increase as seismic intensity increases. As a consequence, also the ductility demands tend to remain concentrated in the mid-lower storeys of the building, in accordance with what observed in Cardone et al. (2017). Comparing NTHA results for the building models with and without IP/OOP interaction, negligible differences in terms of interstory drift profiles are observed (see Fig. 8), regardless the seismic intensities.

This can be explained considering the strong degrading in-plane behavior of the infills, while increasing the interstory drift beyond the peak strength (see Fig. 9), regardless the displacement (hence damage) experienced in the out-of-plane direction. In other words, the IP degrading behavior of the infill strongly affects the OOP performance of the infill but not vice versa. That's why, in most cases, the removal of some infills (due to OOP collapse) does not change significantly the maximum drift profile, which is still basically governed by the in-plane mechanical behavior of the infills registered before the removal.
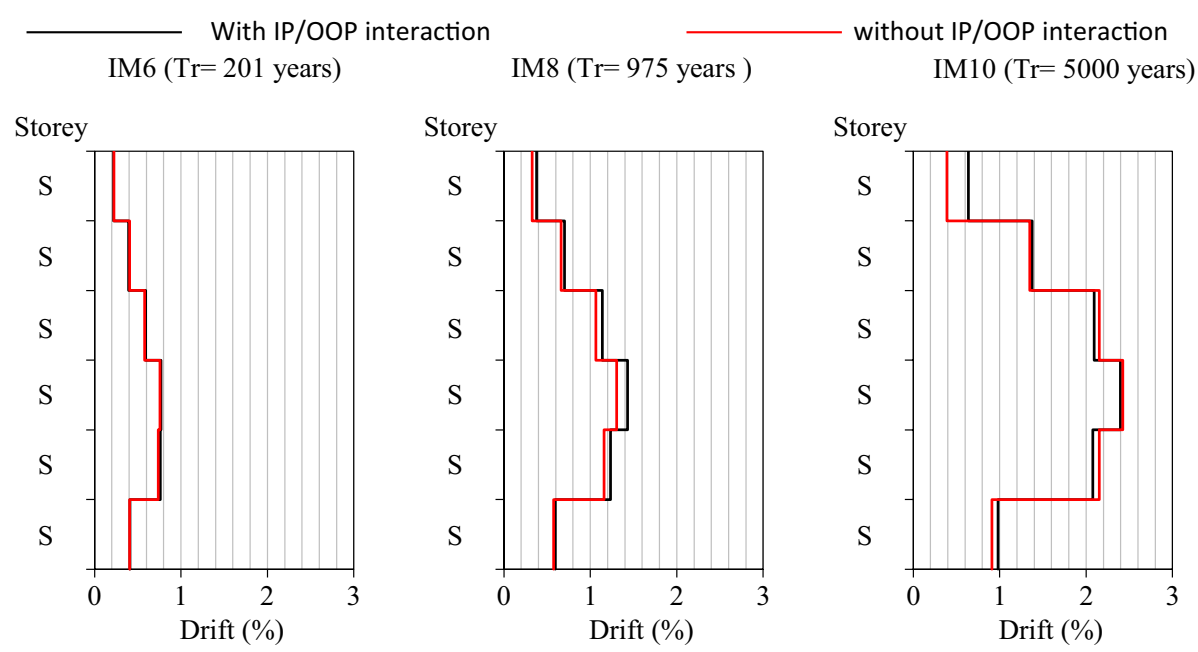

Fig. 8 Maximum interstory drift profiles for the SSD-6st building model, considering or neglecting IP/OOP interaction 


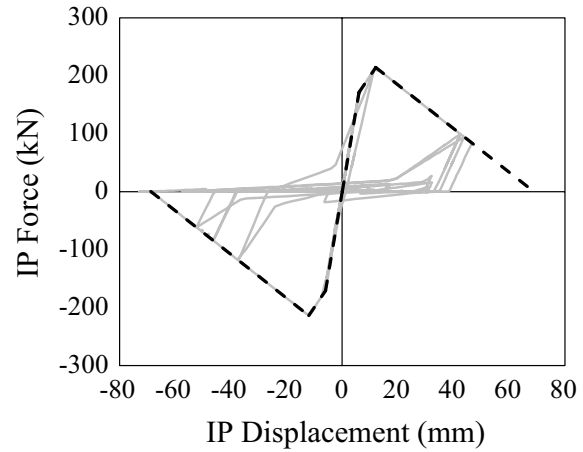

(a)

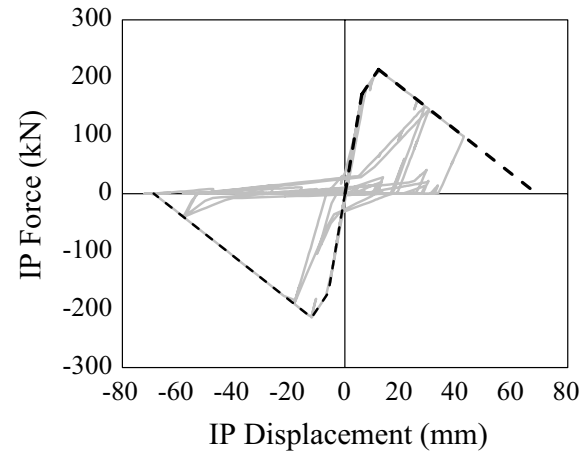

(b)

Fig. 9 Typical IP force versus displacement cyclic behavior of infills observed during NTHA (IM9) at the a 3rd and $\mathbf{b}$ 4th storey of the SSD-6st building located in L'Aquila

\subsection{Damage scenario of masonry infills}

Figures 10, 11 and 12 show typical damage scenarios of masonry infills derived from NTHA. Results considering IP/OOP interaction for the infills are compared to results neglecting IP/OOP interaction. Based on the results of this study, which focuses on typical residential RC frame buildings, realized in Italy between 50s and 90s, the following observations can be made:

(i) The OOP collapse mechanism is relevant only for the double-layer infills (with $100+100 \mathrm{~mm}$ thickness, like those used in GLD and SSD buildings) due to the higher slenderness of the walls;

(ii) The extent of damage is overall greater considering IP/OOP interaction. However, when IP/OOP interaction is neglected, the frequency of occurrence of severe IP damage or IP collapse increases;

(iii) Comparing the performance of GLD and SSD building models (both featuring double-layer infills but differing in the structural characteristics of the frame and seismic hazard of the site), one can note that damage to infills is much more widespread and severe for the building located in the site with higher seismicity (L'Aquila), while it is little influenced by the best structural characteristics of the building model (SSD vs. GLD building models). The higher energy content of the L'Aquila records implies more loading cycles and larger displacement amplitudes, hence more pronounced IP/OOP strength and stiffness degradation experienced by masonry infills.

(iv) The progressive strength and stiffness degradation due to IP/OOP interaction plays a fundamental role in the onset, extension and severity of infill damage, especially for medium- and high-rise buildings. Considering the 8 -storey SSD building located in L'Aquila (higher seismic hazard) (see Fig. 10a), for instance, the first OOP collapse of infills occurs at IM2 ( $\operatorname{Tr}=50$ years), at the top floor of the building (higher floor accelerations). As seismic intensity increases, passing from $\mathrm{IM} 3(\mathrm{Tr}=72$ years) to IM6 ( $\mathrm{Tr}=201$ years), OOP collapse of the infills is registered also at the lower storyes (larger interstory drifts). For further increase of seismic intensity (from IM7 $(\operatorname{Tr}=475$ years) to $\operatorname{IM} 8(\operatorname{Tr}=975$ years $)$, infill damage and IP/OOP collapse develop in the mid storeys of the building (mainly 3rd to 5th storey). Finally, at very high 

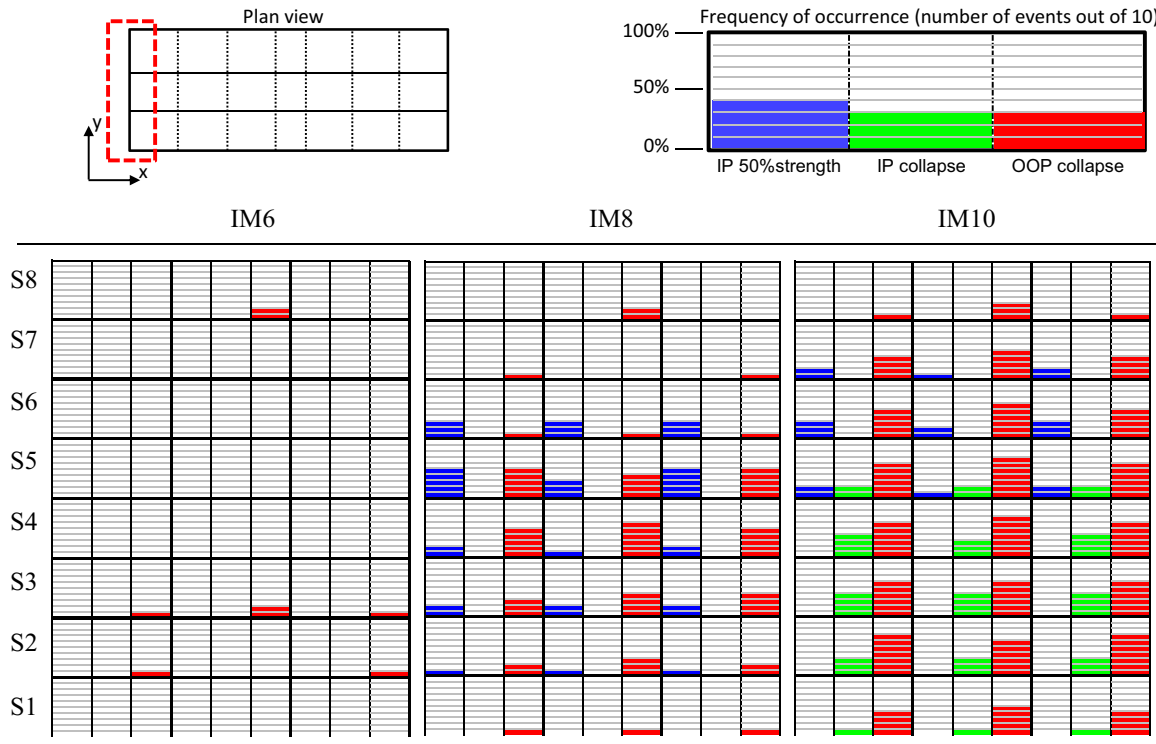

IM10

(a)
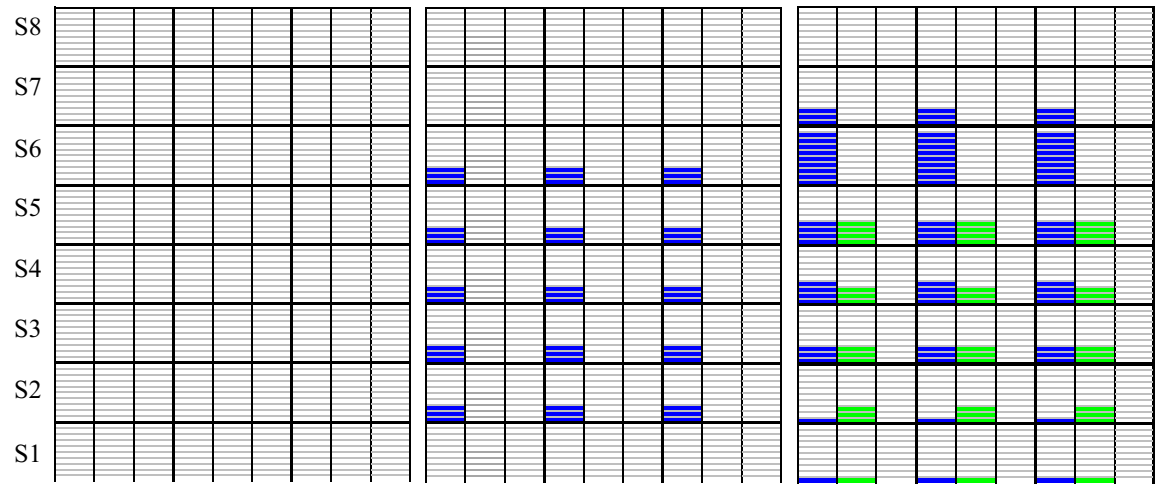

(b)

Fig. 10 Damage scenarios of masonry infills at different earthquake intensity levels for the SSD-st8 building model located in the city of L'Aquila (high seismic hazard), a considering and b neglecting IP/OOP interaction

seismic intensities (i.e. IM9 $(\operatorname{Tr}=2475$ years) and IM10 $(\operatorname{Tr}=5000$ years)), basically all the storeys of the building register a large number of events with severe IP damage and many IP/OOP collapse. Neglecting the IP/OOP interaction (see Fig. 10b), severe damage to the infills start to develop at IM6 ( $\mathrm{Tr}=201$ years), at the mid storeys of the building (mainly 2 nd to 6th storey). While increasing the seismic intensity, severe damage and IP collapse tend to remain concentrated in the mid storeys of the building. First and top storeys are almost not affected by severe damage.

(v) As expected, the seismic intensity at which the first OOP collapse occurs progressively reduces while increasing the number of storeys of the building, being equal to IM6 ( $\mathrm{Tr}=201$ years) for the SSD-4st model, IM4 $(\mathrm{Tr}=101$ years) for the SSD-6st model and IM2 ( $\mathrm{Tr}=50$ years) for the SSD-8st model. 

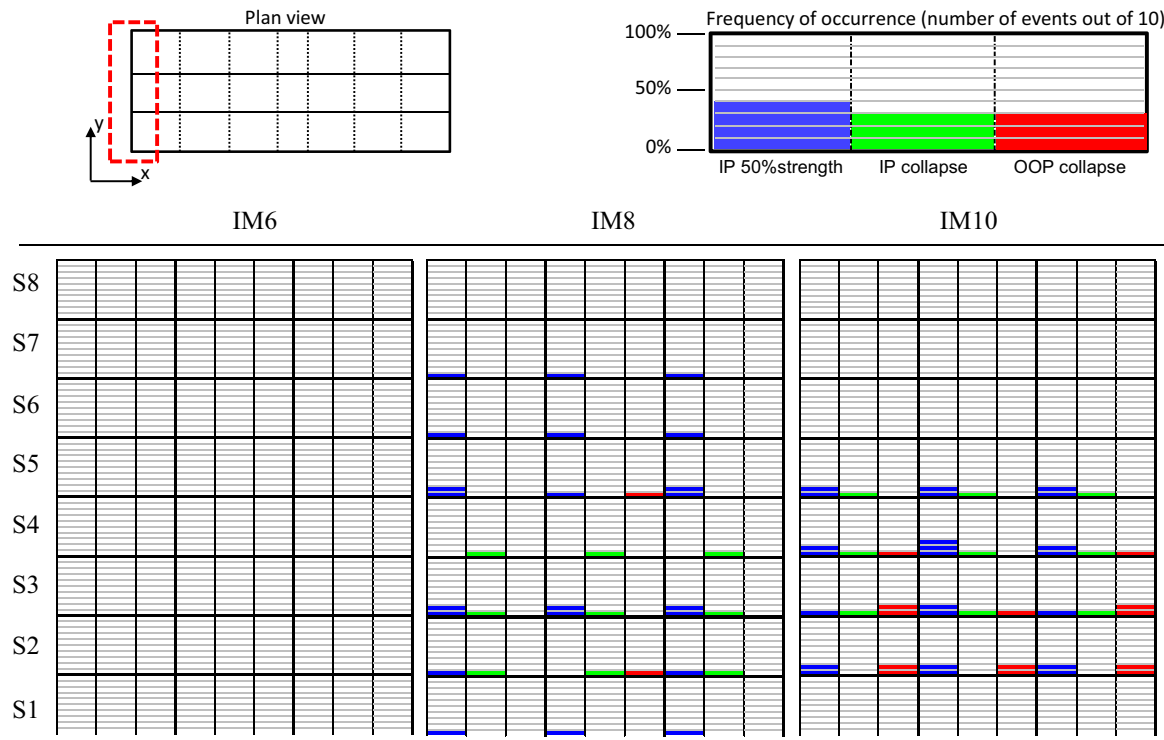

IM8

IM10
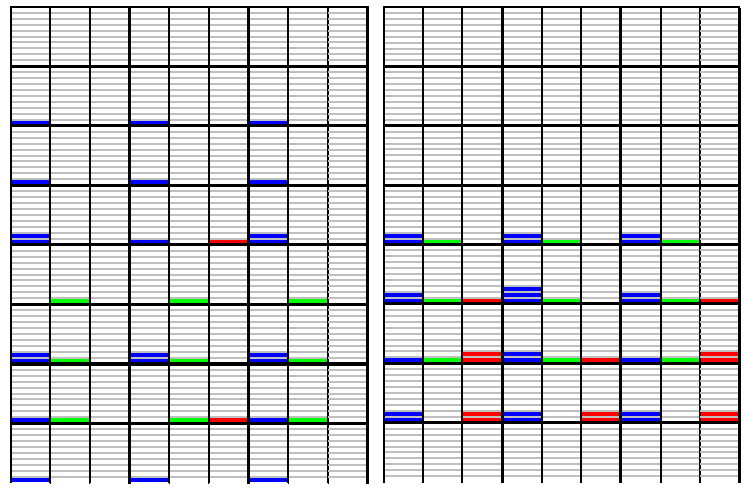

(a)
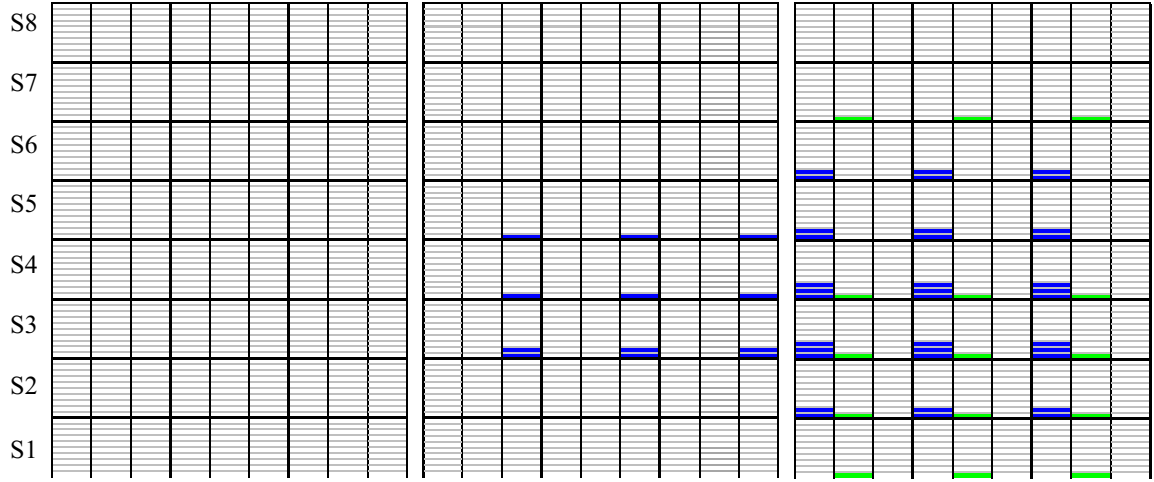

(b)

Fig. 11 Damage scenarios of masonry infills at different earthquake intensity levels for the GLD-st8 building model located in the city of Napoli (medium seismic hazard), a considering and $\mathbf{b}$ neglecting the IP/ OOP interaction

(vi) The OOP collapse of the first infill tend to precede (first event occurs for lower seismic intensities) the onset of severe IP damage for mid- and high-rise buildings (IM2 vs. IM7 for the SSD-8st building model, IM4 vs. IM5 for the SSD-6st building model), while the contrary holds for low-rise buildings (IM6 vs. IM4 for the SSD-4st building model).

(vii) The first OOP collapse takes place at the upper storeys (higher floor accelerations) for high-rise building (e.g. at the 7th storey for the SSD-8st building), while at mid storeys (larger interstory drifts) for mid-to-low rise buildings (e.g. at the 3rd storey for the SSD-6st building and 2nd storey for the SSD-4st building). The HSD building models, featuring single-layer infills with lower slenderness ratio $(\mathrm{h} / \mathrm{t}=8.33)$, 

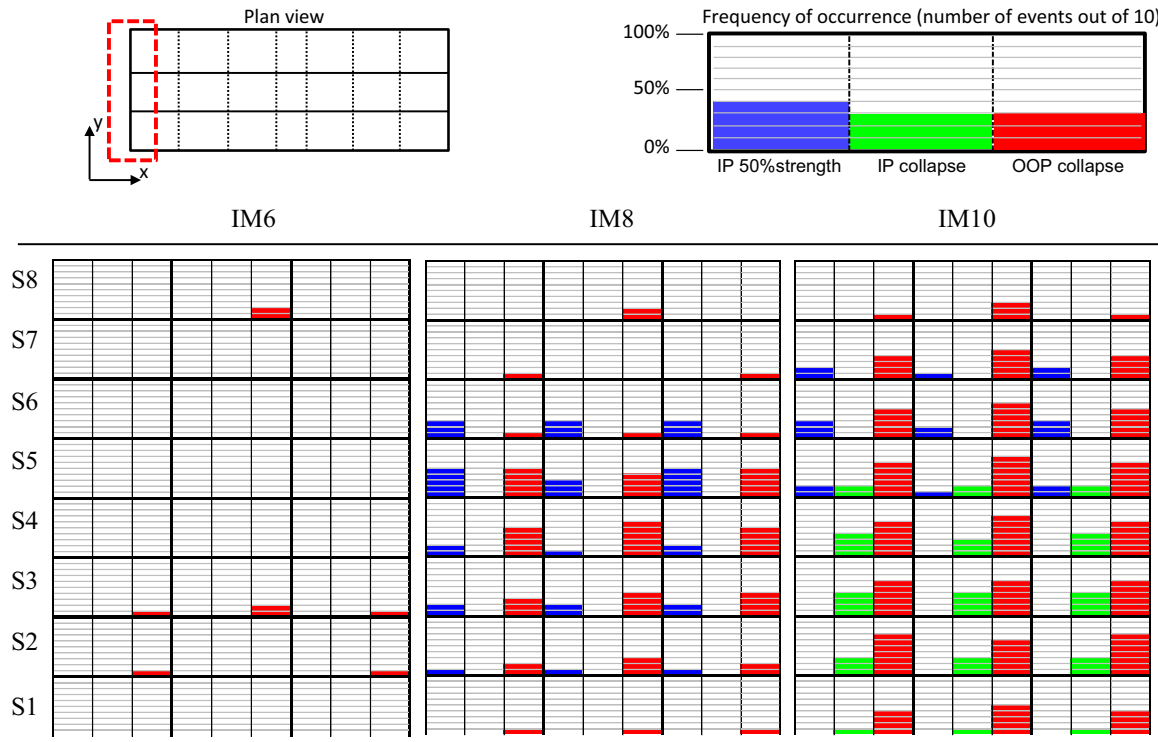

IM8

IM10
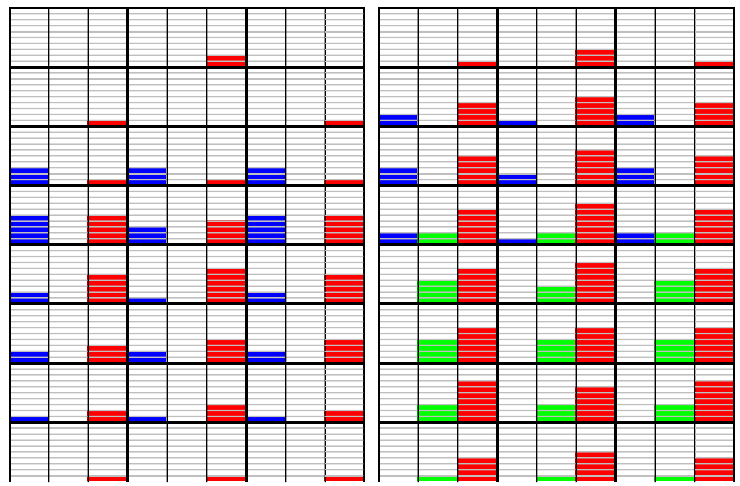

(a)
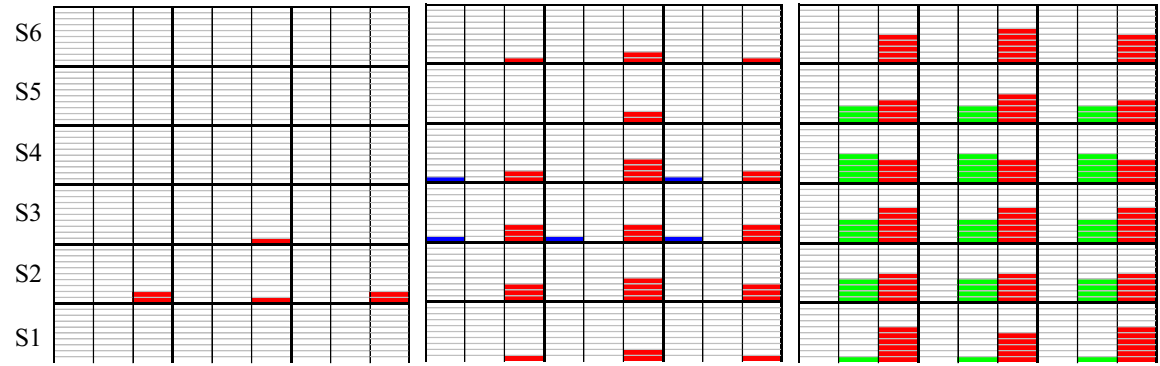

(b)
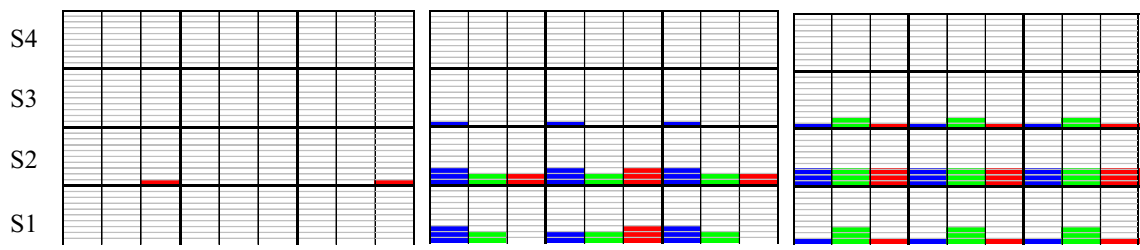

(c)

Fig. 12 Damage scenarios of masonry infills at different earthquake intensity levels considering IP/OOP interaction: a SSD-st8, b SSD-st6 and c SSD-st4 building models located in the city of L'Aquila (high seismic hazard)

do not experience any OOP collapse, even at the highest seismic intensities (i.e. IM9-IM10) during which only the IP collapse of the infills located at the mid-lower storeys (higher IDR values) is observed. A critical issue regards the relative importance between slenderness ratio $(\mathrm{h} / \mathrm{t})$ and in-plane damage towards the occurrence of OOP collapse. To this end, further NTHA have been run by replacing the single-layer infills (300 mm thickness) with the double-layer infills $(100+100 \mathrm{~mm}$ thickness) in 
the HSD-8st building model. Comparing the seismic response and damage scenario of HSD-8st and SSD-8st building models, both with double-layers infills, it turns out that the percentage of infills that undergo OOP collapse is significantly different, being (on average) equal to $34 \%$ for the HSD model and 52\% for the SSD model at IM10, due to an increase of the average (over the height of the building) maximum IDR of the order of $20 \%$. This proves that, although the slenderness of the infill is the main parameter governing its OOP behavior, also the in-plane damage plays a fundamental role.

Table 8 shows the Average Percentage of Damage (APD) as a function of IM for the building models with IP/OOP interaction. The values reported in Table 8 represent the percentage of infills (average over 10 ground motion pairs) that experience: (i) Not-Repairable IP damage (NR(IP)) due to exceedance of the drift corresponding to a reduction of $50 \%$ of the infill strength; and (ii) Out-Of-Plane (OOP) collapse. Similar results are shown in Table 9 for the building models without IP/OOP interaction (in that case only the NR(IP) index is reported because OOP collapse is neglected).

The APD index is computed with the following equation:

$$
A P D=\frac{1}{10} \sum_{i=1}^{10} \frac{N_{\text {damage }, i}}{N_{\text {infill }}}
$$

where $\mathrm{N}_{\text {damage, }}$ is the total number of the infills experiencing NR(IP) damage and OOP collapse, respectively, recorded during the "i-th" ground motion while $\mathrm{N}_{\text {infill }}$ is the total number of the infills.

By comparing the results reported in Tables 8 and 9, one can note that considering the IP/ OOP interaction results in a more severe and widespread damage scenario, especially at higher seismic intensity levels. For instance, the values of APD recorded for the models with IP/OOP interaction at IM8-IM10 are (on average) 1.5-1.8 times greater than for the models without IP/OOP interaction. This is mainly due to the significant percentage of infills that experience OOP collapses, especially for the SSD-6st and SSD-8st building models. For the SSD-4st building model, instead, the NR(IP) damage is preponderant (compared to OOP damage) even at the higher seismic intensities for two main reasons: (i) the lower acceleration demand at the upper storeys and (ii) the higher IDR at the lower storeys due to the lower fundamental period of vibration of the building.

\subsection{Code-conforming safety verifications of OOP collapse mechanisms}

For the models without IP/OOP interaction, the OOP collapse of the infills can be verified by the simplified approaches provided by modern Codes. Herein, reference to the approach proposed in the Italian seismic Code (NTC2018) has been made, in which the OOP collapse of URM infills is checked a posteriori comparing the OOP seismic demand to the infill computed with approximate force relationships $\left(\mathrm{F}_{\mathrm{h}}\right)$ with the OOP strength of the infill $\left(\mathrm{F}_{\max , \mathrm{OOP}}\right)$ derived from reliable formulations from the scientific literature and International Standards. Based on the NTC2018, the OOP seismic demand to the infills can be computed with the following equation:

$$
F_{h}=S_{a} \cdot \frac{W_{a}}{g \cdot q}
$$




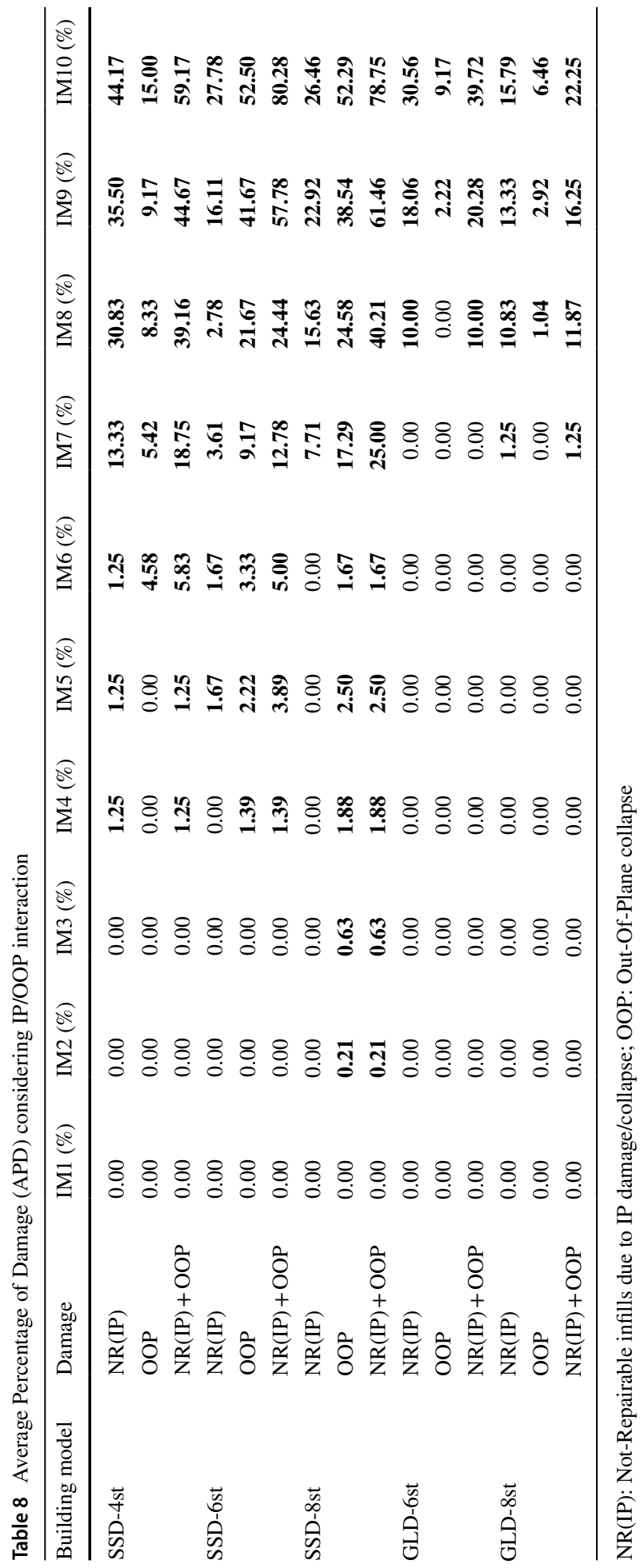




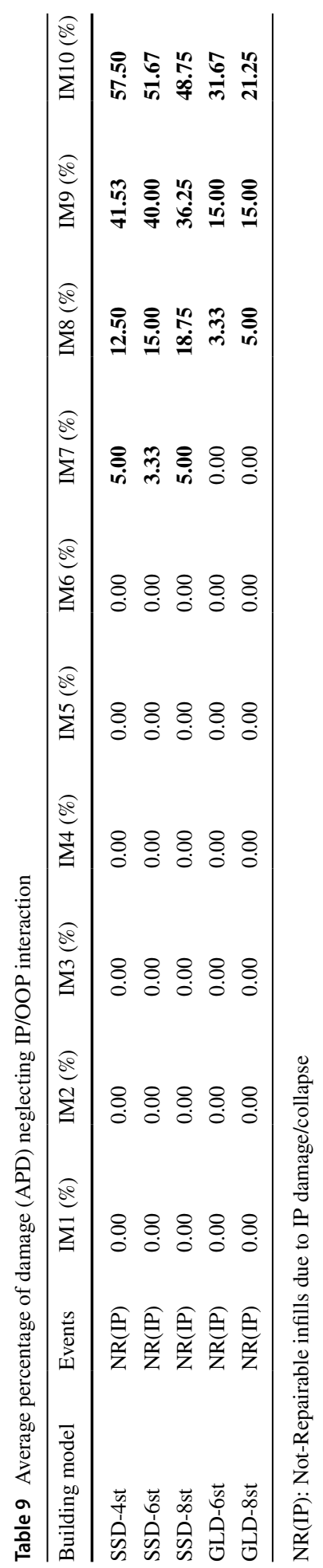


where $S_{a}$ is the seismic coefficient, corresponding to the maximum acceleration experienced by the infill wall, which can be estimated by semi-empirical relationships as a function of: (i) Peak Ground Acceleration (PGA), (ii) fundamental periods of vibration of the building $\left(\mathrm{T}_{1}\right)$ and infill wall $\left(\mathrm{T}_{\mathrm{a}}\right)$ in the OOP direction, (iii) building height $(\mathrm{H})$, (iv) height of the non-structural element from the ground level $(\mathrm{z}) ; \mathrm{W}_{\mathrm{a}}$ is the weight of each single layer of the infill; $\mathrm{g}$ is the acceleration of gravity $\left(9.81 \mathrm{~m} / \mathrm{sec}^{2}\right)$; $\mathrm{q}$ is the behavior factor of the infill, taken equal to 1 in accordance with (NTC2018).

As far as the infill strength $\left(\mathrm{F}_{\max , \mathrm{OOP}}\right)$ is concerned, lacking specific indications in the Italian seismic Code, reference to the formulations reported in three well-known International Standards has been made. They include the Eurocode 6 (2005) (see Eq. (7)), the NZSEE-2017 (2017) (see Eq. (8)) and FEMA-306 (2000) (see Eq. (9)), which provide the OOP strength of the infill as a function of the main geometric characteristics (thickness: $\mathrm{t}$, height: h, and width: w, all expressed in $\mathrm{mm}$ ) and mechanical properties (compressive strength in the vertical direction: $\mathrm{f}_{\mathrm{m}}$, expressed in $\mathrm{MPa}$ or $\mathrm{N}$ ) of the infill.

$$
\begin{gathered}
F_{\text {max }, O O P}(E C 6,2005)=\left[f_{m v} \cdot\left(\frac{t}{h}\right)^{2}\right] \cdot w \cdot h \\
F_{\text {max }, \text { OOP }}(N Z S E E, 2017)=\left[730 \gamma\left(f_{m v}\right)^{0.75} t^{2}\left(\frac{\alpha}{w^{2.5}}+\frac{\beta}{h^{2.5}}\right)\right] \cdot w \cdot h \\
F_{\text {max }, O O P}\left(\text { FEMA306, 2000) }=\left[\frac{2 f_{m v}}{(h / t)} \cdot R_{1} R_{2} \lambda\right] \cdot w \cdot h\right.
\end{gathered}
$$

It is worth noting that, unlike the EC6 (2005), the NZSEE-2017 (2017) and FEMA 306 (1998) code provisions explicitly take into account possible OOP strength reduction due to IP damage through the coefficients $\gamma$ (see Eq. (8)) and $\mathrm{R}_{1}$ (see Eq. (9)), respectively. In particular, the coefficient $\gamma$ is expressed as a function of the infill vertical slenderness ratio $(h / t)$, while $R_{1}$ is expressed as a function of $h / t$ and of the entity of IP damage, assumed as moderate in this study (ref. to Table 8-5 of FEMA-306 (1998)). Moreover, the NZSEE-2017 (2017) and FEMA-306 (1998) take also into account the deformability of the surrounding RC frame, through the coefficients $\alpha$ and $\beta$ (see Eq. (8)) and the coefficient $\mathrm{R}_{2}$ (see Eq. (9)), respectively, which depend on the flexural rigidity of the adjacent RC beams and columns. Assuming the slenderness ratio ( $\lambda$ ) equal to 0.015 (see Eq. (9)), the OOP strength provided by the FEMA-306 approximately coincides with that predicted by the NZSEE-2017.

Figure 13 shows the outcome of the code-conforming OOP collapse safety verifications for the SSD and GLD building models. For comparison, in the same figure there is also a brief summary of the NTHA results derived from the model with IP/OOP interaction. In the latter case, OOP collapse is deemed to occur when for at least one panel of that storey OOP collapse is observed during, at least, 50\% of seismic events. Looking at Fig. 13, one can conclude that the Eurocode 6 (2005) formulation is not conservative, overestimating the OOP capacity of masonry infills, especially at the mid-to-lower storeys of the building. On the other hand, the approaches proposed in the NZSEE-2017 (2017) and FEMA-306 (1998) tend to be too conservative, especially for low-rise buildings.

The Code-conforming safety verifications for the HSD building models located in the city of L'Aquila, do not predict any OOP collapse, in good accordance with the NTHA results. 


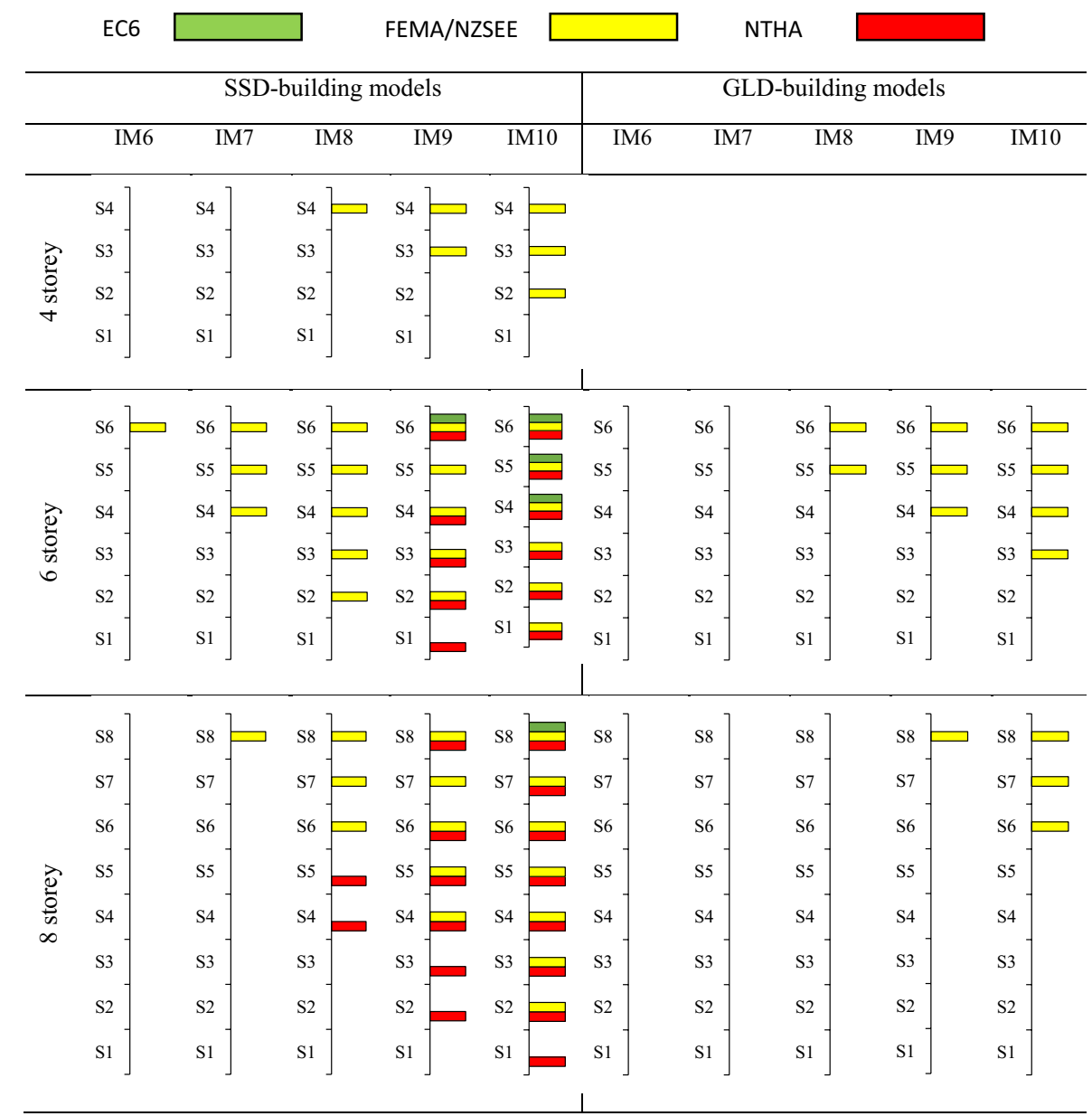

Fig. 13 Comparison between NTHA results and Code-conforming safety verification of OOP collapse mechanisms for (left) SSD building models located in the city of L'Aquila (high seismic hazard) and (right) GLD building models located in the city of Napoli (medium seismic hazard)

Table 10 compares the percentages of infills that undergo OOP collapse derived considering three alternative approaches, i.e.: (i) NTHA of the model with IP/OOP interaction, (ii) code-conforming OOP safety verifications using either EC6 or FEMA/NZSEE relationships.

Based on NTHA results (see Table 10), FEMA/NZSEE code provisions seem to overestimate the number of OOP collapses (conservative approach) in a wide range of seismic intensities ( $\mathrm{Tr} \geq 200$ years) for the SSD building models located in L'Aquila (high seismic hazard for Italy) and also at the highest seismic intensities ( $\operatorname{Tr} \geq 975$ years) for the GLD building models located in Naples (medium seismic hazard). Considering the SSD-6st building model, for instance, the FEMA/NZSEE standards predict OOP collapse for the $80 \%$ to $100 \%$ of infills at IM8-IM10, while the same percentage turns out to be (on average) 4 times less at IM8 and 2 times less at IM9-IM10 based on NTHA 


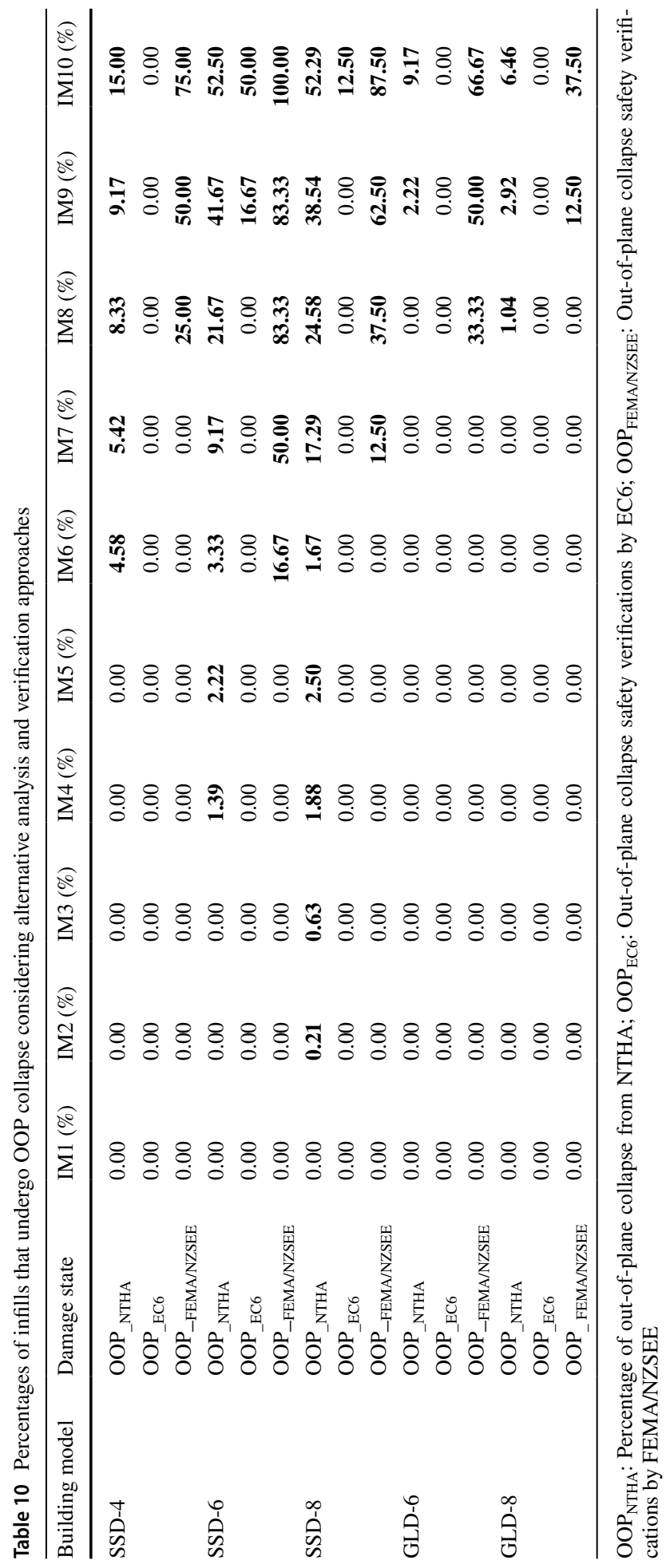


results. On the other hand, the approach proposed in the EC6 appears poorly conservative, especially for the SSD building models located in high seismicity region.

\section{Developing fragility curves}

Fragility Curves (FCs) associated with the attainment of UPD and LS performance levels (see Table 6) have been derived for the GLD and SSD building models, based on the NTHA results of the models with and without IP/OOP interaction. The GC performance level has been neglected because the frequency of occurrence of seismic events associated with the attainment of this PL was always less than $50 \%$.

FCs are expressed by a cumulative lognormal distribution with median value $\vartheta$ and logarithmic standard deviation (or dispersion) $\beta$. FCs provides the conditional probability of the building models to exceed given Performance Levels (PLs), as a function of given seismic intensity measures. Herein, FCs have been developed in terms of spectral acceleration at the effective period of vibration of the buildings (mean value in the two horizontal directions), $\mathrm{S}_{\mathrm{a}}\left(\mathrm{T}^{*}\right)$, defined for each IM considering the seismic hazard of the site (see Table 3).

A best fit regression analysis of the frequencies of occurrence of seismic records associated with the attainment of each PL has been performed to derive the median $\vartheta$ and dispersion $\beta_{\mathrm{r}}$ due to record-to-record variability. Figure 14 shows the fitted lognormal cumulative distribution functions associated with UPD and LS performance levels, separately for the models with and without IP/OOP interaction.

As expected, for a given probability of exceedance (e.g. 50\%), the spectral accelerations corresponding to the attainment of LS performance level are greater than those associated with the UPD performance levels. However, the margin reduces while increasing the number of storeys of the building.

Figure 14 points out that when IP/OOP interaction is considered, the UPD performance level would not be likely to be observed (probability of occurrence less than 10\%) for spectral accelerations (on average) smaller than around $0.18 \mathrm{~g}$ (with a lowest value of $0.13 \mathrm{~g}$ for the GLD-8st buildings and a maximum value of $0.27 \mathrm{~g}$ for the SSD-4st building), but it is almost certain to occur (probability of occurrence greater than 90\%) for spectral accelerations (on average) greater than around $0.35 \mathrm{~g}$ (with a lowest value of $0.27 \mathrm{~g}$ for the GLD8st building and a maximum value of $0.50 \mathrm{~g}$ for the SSD-4st building). Neglecting IP/OOP interaction for the infills, the aforesaid average values increase to $0.20 \mathrm{~g}$ (probability of occurrence less than 10\%) and to $0.45 \mathrm{~g}$ (probability of occurrence greater than $90 \%$ ). As a consequence, one can conclude that the UPD performance level is little affected by the IP/ OOP interaction of URM infills.

Taking into account IP/OOP interaction of infills in the model, the LS performance level is not likely to be observed (probability of occurrence less than 10\%) for spectral accelerations (on average) smaller than around $0.36 \mathrm{~g}$ (with a minimum value of $0.20 \mathrm{~g}$ for the SSD-8st building and a maximum value of $0.56 \mathrm{~g}$ for the SSD-4st building), but it is almost certain to occur (probability of occurrence greater than 90\%) for spectral accelerations (on average) greater than around $0.83 \mathrm{~g}$ (with a minimum value of $0.62 \mathrm{~g}$ for the SSD-8st building and a maximum value of $1.00 \mathrm{~g}$ for the SSD-4st building). Neglecting IP/OOP interaction, the aforesaid values increase (on average) to $0.59 \mathrm{~g}$ (probability of occurrence less than 10\%) and to $0.94 \mathrm{~g}$ (probability of occurrence greater than $90 \%$ ), respectively.

The same trend is observed for the GLD buildings. Considering the IP/OOP interaction, indeed, the LS performance level is not likely to be observed (probability of 


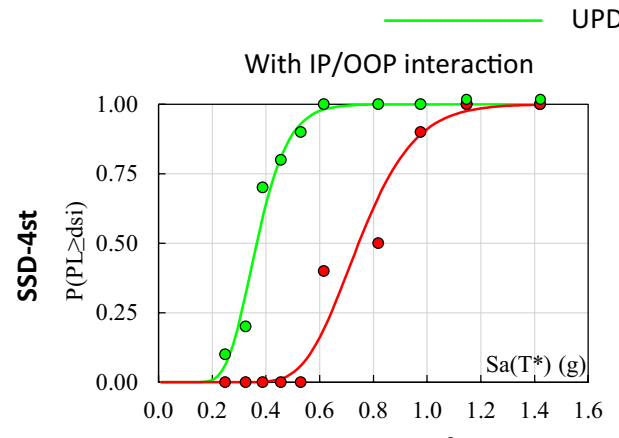

JPD
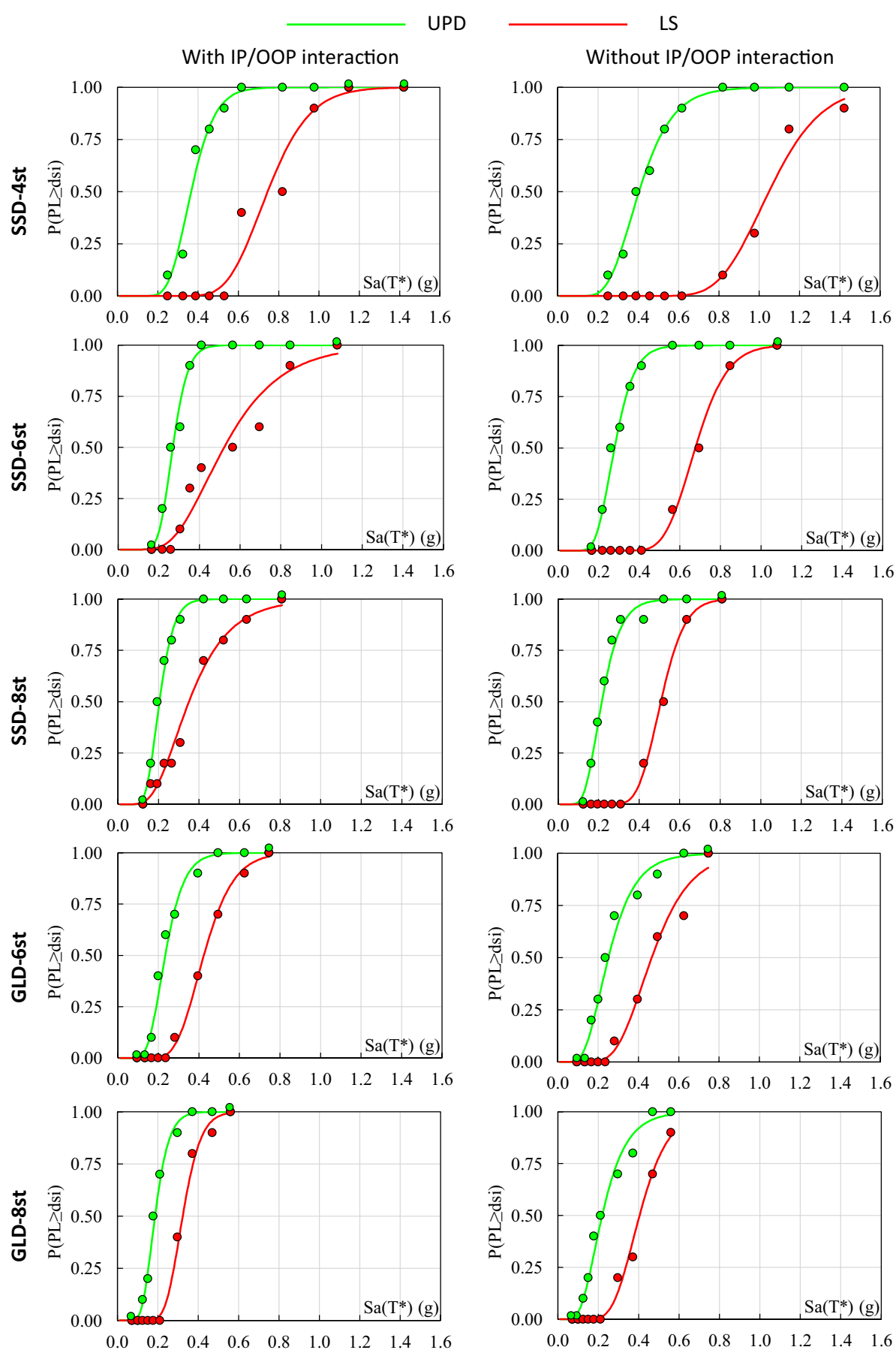

Fig. 14 Fragility curves associated with UPD and LS performance levels for SSD and GLD building models 
occurrence less than 10\%) for spectral accelerations (on average) smaller than around $0.27 \mathrm{~g}$ but it is almost certain to occur (probability of occurrence greater than $90 \%$ ) for spectral accelerations (on average) greater than around $0.51 \mathrm{~g}$. Neglecting IP/OOP interaction, the aforesaid average values increase to $0.30 \mathrm{~g}$ and $0.64 \mathrm{~g}$, respectively. As a consequence, one can conclude that the LS performance level is significantly affected by the IP/OOP interaction of infills, especially in high seismicity regions.

Table 11 summarizes the median values (in terms of spectral acceleration at the fundamental period of vibration of the building) and dispersion due to record-to-record variability of the fragility curves derived. As a matter of fact, neglecting the IP/OOP interaction of infills, the median values (50\% probability of exceedance) associated with LS performance level increase on average by about $38 \%$ for SSD building models located in L'Aquila (high seismic hazard), and by about $18 \%$ for the GLD building models located in Naples (moderate seismic hazard).

Looking at Table 11, one can note that the median values reduce with increasing the number of storeys of the building. For instance, median values associated with the attainment of the UPD (LS) performance levels reduce from approximately $0.37 \mathrm{~g}$ $(0.75 \mathrm{~g})$ for the SSD-4st model to $0.27 \mathrm{~g}(0.52 \mathrm{~g})$ for the SSD-6st model and $0.21 \mathrm{~g}$ $(0.35 \mathrm{~g})$ for the SSD-8st model, due to the premature OOP collapse of some infills. A similar trend is observed also for the GLD building models.

It is interesting to note that, despite the differences in terms of seismic hazard and structural characteristics between GLD and SSD building models, the median values associated with the attainment of UPD and LS performance levels differ no more than $20 \%$, meaning that the most important parameter is represented by the type of infill and its characteristics.

Generally speaking, the total dispersion of a FC, $\beta$, should take into account also other sources of uncertainty, beyond record-to-record variability $\left(\beta_{\mathrm{r}}\right)$. They include (i) the modeling variability $\left(\beta_{\mathrm{m}}\right)$ and (ii) the uncertainty in the definition of the threshold limits of each PL $\left(\beta_{\mathrm{th}}\right)$. In first approximation, in accordance with ATC-58 (2012), $\beta_{\mathrm{m}}$ can be assumed equal to 0.1 for the model with IP/OOP interaction and equal to 0.4 for the model without IP/OOP interaction, considering the quality and completeness of the numerical model used in the analysis (including the relevance of the semi-empirical relationships adopted for the description of the IP/OOP degrading behavior of masonry infills and the representativeness of the experimental data considered to derive those relationships). As far as $\beta_{\text {th }}$ is concerned, values of the order of $0.1-0.3$ can be assumed in accordance with Spillatura (2017). In first approximation, the three dispersion values

Table 11 Values of median spectral acceleration $\mathrm{Sa}\left(\mathrm{T}^{*}\right)(\vartheta)$ and corresponding dispersion due to record-to-record variability $\left(\beta_{\mathrm{r}}\right)$ of the fragility curves associated with UPD and LS performance levels

\begin{tabular}{|c|c|c|c|c|c|c|c|c|}
\hline \multirow[t]{3}{*}{ Building model } & \multicolumn{4}{|c|}{ With IP/OOP interaction } & \multicolumn{4}{|c|}{$\begin{array}{l}\text { Without IP/OOP interac- } \\
\text { tion }\end{array}$} \\
\hline & \multicolumn{2}{|l|}{ UPD } & \multicolumn{2}{|l|}{ LS } & \multicolumn{2}{|l|}{ UPD } & \multicolumn{2}{|l|}{ LS } \\
\hline & $\theta$ & $\beta_{\mathrm{r}}$ & $\theta$ & $\beta_{\mathrm{r}}$ & $\theta$ & $\beta_{\mathrm{r}}$ & $\theta$ & $\beta_{\mathrm{r}}$ \\
\hline SSD-4st & 0.37 & 0.25 & 0.75 & 0.22 & 0.40 & 0.32 & 1.05 & 0.19 \\
\hline SSD-6st & 0.27 & 0.22 & 0.52 & 0.42 & 0.28 & 0.27 & 0.68 & 0.18 \\
\hline SSD-8st & 0.21 & 0.27 & 0.35 & 0.45 & 0.22 & 0.34 & 0.51 & 0.18 \\
\hline GLD-6st & 0.23 & 0.31 & 0.42 & 0.27 & 0.25 & 0.41 & 0.47 & 0.32 \\
\hline GLD-8st & 0.19 & 0.29 & 0.32 & 0.22 & 0.21 & 0.43 & 0.40 & 0.28 \\
\hline
\end{tabular}


can be combined using the square root of the sum of squares rule, while keeping the same median value.

\section{Conclusions and further developments}

In this paper, the influence of the interaction between In-Plane (IP) and Out-Of-Plane (OOP) behavior of masonry infills on the seismic performance of typical residential RC buildings, realized in Italy between 50's and 90's, has been examined.

Accurate 3D lumped plasticity models of infilled RC frame buildings have been implemented in OpenSEES. A V-shaped bi-diagonal strut macro-element has been used for masonry infills, adopting the modelling approach proposed by Di Domenico et al. (2017) and the semi-empirical relationships derived by Ricci et al. (2018a, b) to account for the IP/OOP interaction of infills.

Seven archetype buildings, differing in terms of age of construction (50's to 90's), number of storeys (from 4 to 8), seismic design approach (gravity loads design, low seismic forces with substandard details, modern seismic design) and type of masonry infills (thin double-layers infills with inner cavity and thick single-layer infills) have been analyzed. The building models have been located in two different sites (Napoli and L'Aquila), featuring moderate and high seismic hazard for Italy, respectively.

Extensive Nonlinear response-Time History Analysis (NTHA) have been carried out for ten earthquake intensity levels, with return periods ranging from 30 to 5000 years. Seismic performances have been evaluated considering two different Performance Levels (PLs), referred to as: Usability Preventing Damage (UPD), and Life Safety (LS). NTHA have been repeated considering a non-degrading IP-only model for infills, in order to assess the relevance of the IP/OOP interaction and degrading behavior of masonry infills towards the seismic performance of RC frame buildings. Code-conforming simplified approaches, adopted in current practice, have been considered for the models without IP/OOP interaction, in order to check a posteriori the OOP collapse of infills.

Based on the results of this study, the following main conclusions can be drawn:

(i) Although the slenderness ratio $(\mathrm{h} / \mathrm{t})$ is the main parameter governing the OOP behavior of URM infills, also the in-plane damage plays a fundamental role towards the OOP seismic performance of the infills;

(ii) The OOP collapse mechanism results particularly relevant for double-layer infills characterized by relatively high values of slenderness $(\mathrm{t} / \mathrm{h} \approx 25-30)$; Single-layer infills, characterized by relatively low values of the slenderness $(\mathrm{t} / \mathrm{h} \approx 8-10)$, are little affected by IP/OOP interaction;

(iii) For mid- and high-rise RC buildings with double-layer infills, considering the IP/OOP interaction of infills in the numerical model can lead to significantly worse predictions in terms of damage to non-structural elements at high seismic intensities (number of collapsed or not repairable infills up to 1.5-2 times greater than that predicted by building models without IP/OOP interaction);

(iv) The simplified approaches proposed in the modern codes for the safety verification of the OOP collapse mechanisms of infills can significantly overestimate (ref. to FEMA306/NZSEE-2017) or underestimate (ref. to EC6) the number of OOP collapses;

(v) Considering the IP/OOP interaction of URM infills in the numerical model does not influence a lot the Usability-Preventing Damage (UPD) performance level of RC build- 
ings (changes in the median values of fragility curves less than $10 \%$ in terms of spectral acceleration) but can significantly affect the seismic performance of the RC buildings in terms of Life Safety (LS) performance level (changes in the median values of fragility curves (on average) greater than $30 \%$ in terms of spectral acceleration).

In this study, the local effects of masonry infills on the surrounding frame have been neglected. As known, the lateral force transmitted by the infill to the top of adjacent RC columns may trigger premature brittle shear failure of such structural elements. This is particularly relevant for older RC frame buildings, designed for gravity loads only or featuring substandard seismic details. Future developments of this research should address this concern. Another issue to be addressed is the extension of the model by Di Domenico et al. (2017) to masonry infills with openings.

Acknowledgements Open access funding provided by Università degli Studi della Basilicata within the CRUI-CARE Agreement.

Open Access This article is licensed under a Creative Commons Attribution 4.0 International License, which permits use, sharing, adaptation, distribution and reproduction in any medium or format, as long as you give appropriate credit to the original author(s) and the source, provide a link to the Creative Commons licence, and indicate if changes were made. The images or other third party material in this article are included in the article's Creative Commons licence, unless indicated otherwise in a credit line to the material. If material is not included in the article's Creative Commons licence and your intended use is not permitted by statutory regulation or exceeds the permitted use, you will need to obtain permission directly from the copyright holder. To view a copy of this licence, visit http://creativecommons.org/licenses/by/4.0/.

\section{References}

Angel R, Abrams DP, Shapiro D, Uzarski J, Webster M (1994) Behavior of reinforced concrete frames with masonry infills. Department of Civil Engineering, University of Illinois, Urbana-Champaign, IL

Asteris P, Cotsovos DM, Chrysostomou CZ et al (2013) Mathematical micromodeling of infilled frames: state of the art. Eng Struct 56:1905-1921

ATC - Applied Technology Council, FEMA P-58 (2012) Next-generation seismic performance assessment for buildings, volume 1-methodology. Federal Emergency Management Agency, Washington, DC

Ay BÖ, Fox MJ, Sullivan TJ (2017) Technical note: practical challenges facing the selection of conditional spectrum compatible accelerograms. J Earthq Eng 21(1):169-180

Baker JW (2011) Conditional mean spectrum: tool for ground motion selection. J Struct Eng 137(3):322-331

Bashandy T, Rubiano NR, Klingner RE (1995) Evaluation and analytical verification of infilled frame test data. Phil M. Ferguson Structural Engineering Laboratory, University of Texas at Austin

Braga F, Manfredi V, Masi A, Salvatori A, Vona M (2011) Performance of non-structural elements in RC buildings during the L'Aquila 2009 earthquake. Bull Earthq Eng 9(1):307-324

Braga F, Gigliotti R, Laterza M, D‘Amato M, Kunnath SF (2012) Modified steel bar model incorporating bond-slip for seismic assessment of concrete structures. J Struct Eng ASCE 138:1342-1350

Calvi GM, Bolognini D (2001) Seismic response of reinforced concrete frames infilled with weakly reinforced masonry panels. J Earthq Eng 5:153-185

Calvi GM, Magenes G, Pampanin S (2002) Relevance of beam-column joint damage and collapse in rc frame assessment. J Earthq Eng 6(1):75-100

Cardone D (2007) Nonlinear static methods vs. experimental shaking table test results. J Earthq Eng 11(6):847-875. https://doi.org/10.1080/13632460601173938

Cardone D, Perrone G (2015) Developing fragility curves and loss functions for masonry infill walls. Earthq Struct 9(1):257-279

Cardone D, Perrone G (2017) Damage and loss assessment of pre-70 RC frame buildings with FEMA P-58. J Earthq Eng 21(1):23-61

Cardone D, Sullivan TJ, Gesualdi G, Perrone G (2017) Simplified estimation of the expected annual loss of reinforced concrete buildings. Earthq Eng Struct Dyn 46(12):2009-2032 
CEN (2005) Eurocode 6 (EC6): design of masonry structures-Part 1-1: General Rules for reinforced and unreinforced masonry structures. European Committee for Standardization, Brussels

Circolare Esplicativa 21 gennaio 2019, n. 7 C.S.LL.PP. Istruzioni per l'applicazione dell' "Aggiornamento delle "Norme tecniche per le costruzioni"» di cui al decreto ministeriale 17 gennaio 2018, Rome (in Italian)

Crisafulli FJ, Carr AJ (2007) Proposed macro-model for the analysis of infilled frame structures. Bull N Z Soc Earthq Eng 40(2):69-77

Dawe JL, Seah CK (1989) Out-of-plane resistance of concrete masonry infilled panels. Can J Civ Eng 16(6):854-64

De Luca F, Verderame GM, Gómez-Martínez F, Pérez-García A (2014) The structural role played by masonry infills on RC building performances after the 2011 Lorca, Spain, earthquake. Bull Earthq Eng 12(5):1999-2026

De Risi MT, Di Domenico M, Ricci P, Verderame GM, Manfredi F (2019) Experimental investigation on the influence of the aspect ratio on the in-plane/out-of-plane interaction for masonry infills in RC frames. Eng Struct 189:523-540

Decanini L, Mollaioli F, Mura A, Saragoni R (2004) Seismic performance of masonry infilled R/C frames. In: Proceedings on 13th WCEE, Paper 165, Vancouver, B.C., Canada, 1-6 Aug

Di Domenico M, Ricci P, Verderame GM (2017) Empirical unreinforced masonry infill macro-model accounting for in-plane/out-of-plane interaction. In: COMPDYN 2017-6th international thematic conference, pp 1606-1624

Dolšek M, Fajfar P (2008) The effect of masonry infills on the seismic response of a four-storey reinforced concrete frame-a deterministic assessment. Eng Struct 30:1991-2001

El-Dakhakhni WW, Elgaaly M, Hamid AA (2003) Three-strut model for concrete masonry infilled steel frames. J Struct Eng 129(2):177-185

Fabbrocino G, Verderame GM, Manfredi G, Cosenza E (2004) Structural models of critical regions in oldtype r.c. frames with smooth rebars. Eng Struct 26:2137-2148

Fardis MN, Panagiotakos TB (1997) Seismic design and response of bare and masonry-infilled reinforced concrete buildings. Part II: infilled structures. J Earthq Eng 1:475-503

Federal Emergency Management Agency (1997) NEHRP commentary on the guidelines for the seismic rehabilitation of buildings. FEMA-274, Applied Technology Council, Washington, DC

Federal Emergency Management Agency (1998) Evaluation of earthquake damaged concrete and masonry wall buildings, basic procedures manual. FEMA-306, Washington, DC

Federal Emergency Management Agency (2000) Prestandard and commentary for the seismic rehabilitation of buildings. FEMA-356, Applied Technology Council, Washington, DC

Flanagan RD, Bennett RM (1999) Bidirectional behavior of structural clay tile infilled frames. J Struct Eng 125(3):236-244

Furtado A, Rodrigues H, Arêde H, Varum H (2015a) Influence of the in plane and out-of-plane masonry infill walls' interaction in the structural response of rc buildings. Procedia Eng 114:722-729

Furtado A, Rodrigues H, Arêde A, Varum H (2015b) Simplified macro-model for infill masonry walls considering the out-of-plane behaviour. Earthq Eng Struct Dyn 45:507-524

Guidi G, da Porto F, Dalla Benetta M, Verlato N, Modena C (2013) Comportamento sperimentale nel piano e fuori piano di tamponamenti in muratura armata e rinforzata. In: Proceedings of the XV ANIDIS, L'Ingegneria Sismica in Italia, Padua, Italy, 2013, 30 (in Italian)

Hak S, Morandi P, Magenes G (2014) Out-of-plane experimental response of strong masonry infills. In: 2nd European conference on earthquake engineering and seismology

Hashemi A, Mosalam KM (2007) Seismic evaluation of reinforced concrete buildings including effects of masonry infill walls. Pacific Earthquake Engineering Research Center, University of California, Berkeley

Henderson RC, Porter ML, Jones WD, Burdette EG (2006) Influence of prior out-of-plane damage on the in-plane behavior of masonry infilled frames. TMS J 24(1):71-82

Holmes M (1961) Steel frames with brickwork and concrete infilling. Proc Inst Civ Eng 19:473-478 (eISSN 1753-7789)

Ibarra LF, Medina RA, Krawinkler H (2005) Hysteretic models that incorporate strength and stiffness deterioration. Earthq Eng Struct Dyn 34:1489-1511

ISTAT (2011) Censimento delle Popolazione e delle Abitazioni, 2011. http://dati-censimentopopolazion e.istat.it/\#. Accessed 2 Dec 2015

Kadysiewski S, Mosalam KM (2009) Modeling of unreinforced masonry infill walls considering in-plane and out-of-plane interaction. Pacific Earthquake Engineering Research Center, University of California, Berkeley 
Lam NTK, Griffith M, Wilson J, Doherty K (2003) Time-history analysis of URM walls in out-of-plane flexure. Eng Struct 25:743-754

Longo F, Wiebe L, da Porto F, Modena C (2018) Application of an in-plane/out-of-plane interaction model for URM infill walls to dynamic seismic analysis of RC frame buildings. Bull Earthq Eng 16:6163-6619

Mainstone RJ (1971) On the stiffness and strength of infilled frames. Proc Inst Civ Eng Supplement IV:5790 (paper 7360S)

Masi A, Digrisolo A, Manfredi V (2015) Fragility curves of gravity-load designed RC buildings with regularity in plan. Earthq Struct 9(1):1-27

Masi A, Chiauzzi L, Santarsiero G, Manfredi V, Biondi S, Spacone E, Del Gaudio C, Ricci P, Manfredi G, Verderame GM (2019) Seismic response of RC buildings during the Mw 6.0 August 24, 2016 Central Italy earthquake: the Amatrice case study. Bull Earthq Eng J 17(10):5631-5654

McDowell EL, McKee KE, Sevin E (1956) Arching action theory of masonry walls. J Struct Div 82(2):915

McKenna F, Fenves GL, Scott MH (2000) Open system for earthquake engineering simulation. University of California, Berkeley, CA

Mehrabi AB, Shing PB (1997) Finite element modeling of masonry-infilled RC frames. J Struct Eng 123:604-613

Morandi P, Magenes G, Hak S (2013) Simplified out-of-plane resistance verification for slender clay masonry infills in RC frames. XV Convegno ANIDIS - L'ingegneria Sismica in Italia

Mosalam KM, Günay S (2015) Progressive collapse analysis of RC frames with URM infill walls considering in-plane/out-of-plane interaction. Earthq Spectra 31(2):921-943

New Zealand Society for Earthquake Engineering - NZSEE (2017). The Seismic Assessment of Existing Buildings (the Guidelines), Part C-Detailed Seismic Assessment (for potential EPBs), Wellington, New Zealand. see http://www.eq-assess.org.nz/

NTC2018 (2008) D.M. 17.01.2018. Aggiornamento delle Norme Tecniche per le Costruzioni, Rome (in Italian)

Ozkaynak H, Yuksel E, Yalcin C et al (2013) Masonry infill walls in reinforced concrete frames as a source of structural damping. Earthq Eng Struct Dyn 43:949-968

Panagiotakos TB, Fardis MN (1996) Seismic response of infilled RC frames structures. In: Proceedings on XXI world conference of earthquake engineering, Acapulco, Mexico

Pasca M, Liberatore L (2015) Predicting models for the evaluation of out-of-plane ultimate load carrying capacity of masonry infill walls. WIT Trans Built Environ 152:83-94

Pereira MFP, Pereira MFN, Ferreira JED, Lourenço PB (2011) Behavior of masonry infill panels in RC frames subjected to in plane and out of plane loads. In: 7th international conference on AMCM2011, Kraków, Poland

Perrone G, Cardone D, O'Reilly GJ, Sullivan TJ (2019) Developing a direct approach for estimating expected annual losses of Italian buildings. J Earthq Eng. https://doi.org/10.1080/13632 469.2019.1657988

Polyakov SV (1960) On the interaction between masonry filler walls and enclosing frame when loaded in the plane of the wall. Translations in Earthquake Engineering. EERI, San Francisco, pp 36-42

Ricci P, De Luca F, Verderame G (2011) 6th April 2009 L'Aquila earthquake, Italy: reinforced concrete building performance. Bull Earthq Eng 9(1):285-305

Ricci P, Di Domenico M, Verderame GM (2018a) Experimental assessment of the in-plane/out-of-plane interaction in unreinforced masonry infill walls. Eng Struct 173:960-978

Ricci P, Di Domenico M, Verderame GM (2018b) Experimental investigation of the influence of slenderness ratio and of the in-plane/out-of-plane interaction on the out-of-plane strength of URM infill walls. Constr Build Mater 191:505-522. https://doi.org/10.1016/j.conbuildmat.2018.10.011

Rossetto T, Elnashai A (2003) Derivation of vulnerability functions for European-type RC structures based on observational data. Eng Struct 25(10):1241-1263

Sassun K, Sullivan TJ, Morandi P, Cardone D (2016) Characterising the in-plane seismic performance of infill masonry. Bull N Z Soc Earthq Eng 49(1):100-117

Sezen H, Moehle JP (2004) Shear strength model for lightly reinforced concrete columns. J Struct Eng 130(11):1692-1703

Spillatura A (2017) From record selection to risk targeted spectra for risk based assessment and design. Thesis, IUSS Pavia, Italy

Stafford-Smith B (1962) Lateral stiffness of infilled frames. J Struct Div 88(6):183-199

Smyrou E, Blandon C, Antoniou S, Pinho R, Crisafulli F (2011) Implementation and verifcation of a masonry panel model for nonlinear dynamic analysis of inflled RC frames. Bull Earthq Eng 9(5):1519-1534 
Taghavi S, Miranda E (2002) Seismic performance and loss assessment of nonstructural building components. In: Proceedings of 7th national conference on earthquake engineering, Boston, USA

Trapani FD, Shing PB, Cavaleri L (2018) Macroelement model for in-plane and out-of-plane responses of masonry infills in frame structures. J Struct Eng 144(2):04017198

Vamvatsikos D (2014) Accurate application and second-order improvement of SAC/FEMA probabilistic formats for seismic performance assessment. ASCE J Struct Eng 140(2):04013058. https://doi. org/10.1061/(ASCE)ST.1943-541X.0000774

Varum H, Dumaru R, Furtado A, Barbosa AR, Gautam D, Rodrigues H (2018) Chapter 3-seismic performance of buildings in Nepal after the Gorkha earthquake. In: Gautam D, Rodrigues H (eds) Impacts and insights of the Gorkha earthquake. Elsevier, Amsterdam, pp 47-63

Verderame GM, Manfredi G, Frunzio G (2001a) The mechanical properties of the steels used in reinforced concrete structures built in the 1960s. X Congresso Nazionale ANIDIS, 2001, Italy (in Italian)

Verderame GM, Manfredi G, Frunzio G (2001b) The mechanical properties of the concrete used in reinforced concrete structures built in the 1960s. X Congresso Nazionale ANIDIS, Italy (in Italian)

Vicente RS, Rodrigues H, Varum H, Costa A, Mendes da Silva JAR (2012) Performance of masonry enclosure walls: lessons learned from recent earthquakes. Earthq Eng Eng Vib 11(1):23-34

Publisher's Note Springer Nature remains neutral with regard to jurisdictional claims in published maps and institutional affiliations. 